This is a self-archived version of an original article. This version may differ from the original in pagination and typographic details.

Author(s): $\begin{aligned} & \text { Fei, Wenwen; Antonello, Sabrina; Dainese, Tiziano; Dolmella, Alessandro; } \\ & \text { Lahtinen, Manu; Rissanen, Kari; Venzo, Alfonso; Maran, Flavio }\end{aligned}$

Title: Metal Doping of Au25(SR)18- Clusters : Insights and Hindsights

Year: 2019

Version: Accepted version (Final draft)

Copyright: ㄷ 2019 American Chemical Society

Rights: In Copyright

Rights url: http://rightsstatements.org/page//nC/1.0/?language=en

Please cite the original version:

Fei, W., Antonello, S., Dainese, T., Dolmella, A., Lahtinen, M., Rissanen, K., Venzo, A., \& Maran, F. (2019). Metal Doping of Au25(SR)18- Clusters : Insights and Hindsights. Journal of the American Chemical Society, 141(40), 16033-16045. https://doi.org/10.1021/jacs.9b08228 


\title{
Article
}

\section{Metal Doping of Au(SR) Clusters: Insights and Hindsights}

\author{
Wenwen Fei, Sabrina Antonello, Tiziano Dainese, Alessandro Dolmella, \\ Manu Lahtinen, Kari Rissanen, Alfonso Venzo, and Flavio Maran
}

J. Am. Chem. Soc., Just Accepted Manuscript • DOI: 10.1021/jacs.9b08228 • Publication Date (Web): 18 Sep 2019

Downloaded from pubs.acs.org on September 19, 2019

\section{Just Accepted}

"Just Accepted" manuscripts have been peer-reviewed and accepted for publication. They are posted online prior to technical editing, formatting for publication and author proofing. The American Chemical Society provides "Just Accepted" as a service to the research community to expedite the dissemination of scientific material as soon as possible after acceptance. "Just Accepted" manuscripts appear in full in PDF format accompanied by an HTML abstract. "Just Accepted" manuscripts have been fully peer reviewed, but should not be considered the official version of record. They are citable by the Digital Object Identifier (DOI®). "Just Accepted" is an optional service offered to authors. Therefore, the "Just Accepted" Web site may not include all articles that will be published in the journal. After a manuscript is technically edited and formatted, it will be removed from the "Just Accepted" Web site and published as an ASAP article. Note that technical editing may introduce minor changes to the manuscript text and/or graphics which could affect content, and all legal disclaimers and ethical guidelines that apply to the journal pertain. ACS cannot be held responsible for errors or consequences arising from the use of information contained in these "Just Accepted" manuscripts. 


\section{INTRODUCTION}

Many thiolate-protected gold nanoclusters, especially those sufficiently small (typically, less than ca. 144 atoms) to display electrochemical, ${ }^{1}$ optical, ${ }^{2}$ and magnetic ${ }^{3}$ molecular properties, can be prepared with atomic precision. ${ }^{4,5}$ Recently, research has also been focusing on the selective doping of metal nanoclusters through introduction of foreign-metal atoms. ${ }^{6-9}$ This is a very important area for both fundamental and applied (e.g., catalysis) purposes. Modification of the metal composition has been studied for several clusters, but most research has focused on $\mathrm{Au}_{25}(\mathrm{SR})_{18}$, which is an atomically precise cluster that has been long considered a convenient benchmark system for understanding properties and devising applications of gold nanoclusters. ${ }^{10,11}$

Controlled doping of $\mathrm{Au}_{25}(\mathrm{SR})_{18}{ }^{-}$has been carried out with the noble metals platinum ${ }^{12-16}$ and palladium, ${ }^{14,16-19}$ and less noble metals, such as cadmium ${ }^{20-22}$ and mercury, ${ }^{15,20-23}$ also because of the ease by which monodoping could be achieved with these metals as opposed to, say, copper and silver. ${ }^{9}$ Mass spectrometry and single crystal X-ray crystallography were extensively employed to interpret the doping results and, particularly, assign the specific locations where these single foreign-metal atoms go. The platinum-doped clusters were prepared by direct synthesis, i.e., by reacting a mixture of tetrachloroauric and hexachloroplatinic acids with a given thiol, followed by sodium borohydride reduction. ${ }^{12-15}$ The same procedure was applied to palladium ${ }^{14,16-19}$ and mercury. ${ }^{15}$ Cadmium $^{20-22}$ and mercury ${ }^{20-23}$ were introduced into preformed $\mathrm{Au}_{25}(\mathrm{SR})_{18}{ }^{-}$, and studied from several viewpoints. Regarding cadmium, $\mathrm{Wu}$ and co-workers reported that when the metal source is a salt, $\mathrm{Cd}\left(\mathrm{NO}_{3}\right)_{2}$, doping occurs on the icosahedron. ${ }^{21}$ The analysis of the data pertaining to $\mathrm{Au}_{24} \mathrm{Cd}(\mathrm{SC} 2 \mathrm{Ph})_{18}{ }^{0}$ $(\mathrm{SC} 2 \mathrm{Ph}=$ phenylethanethiolate; hereafter, we will indicate the number of carbon atoms of the alkyl chain simply as $\mathrm{Cn}$ ) relied on X-ray crystallography and theoretical calculations of the experimental UV-vis-NIR spectrum, in comparison with the corresponding mercury monodoped cluster $\mathrm{Au}_{24} \mathrm{Hg}(\mathrm{SC} 2 \mathrm{Ph})_{18}{ }^{0}$ and the pertinent matrix-assisted laser desorption ionization time-of-flight (MALDI-TOF) mass spectrometry fragmentation patterns. The latter also was obtained using a salt as the metal source, $\mathrm{Hg}\left(\mathrm{NO}_{3}\right)_{2}{ }^{23}$ Interestingly, the two very similar syntheses led to doping at different positions: whereas $\mathrm{Cd}$ would go on the icosahedron, ${ }^{21}$ for $\mathrm{Hg}$ the X-ray single-crystal diffraction results were interpreted to indicate that one of the staple $\mathrm{Au}$ atoms is replaced by $\mathrm{Hg}$. Theoretical simulations of the experimental UV-vis-NIR spectrum, and the MALDI-TOF mass-spectrometry, thermogravimetric analysis, and 
electrochemical results provided further support to this conclusion. ${ }^{23}$ Further work used this conclusion to understand what happens when $\mathrm{Ag}$ is used to dope a preformed $\mathrm{Au}_{24} \mathrm{Hg}(\mathrm{SC} 2 \mathrm{Ph})_{18}{ }^{0}$ cluster. ${ }^{24}$ For both $\mathrm{Au}_{24} \mathrm{Hg}(\mathrm{SC} 2 \mathrm{Ph})_{18}{ }^{0}$ and the so-formed trimetallic cluster, the NMR results were taken as a further indication that $\mathrm{Hg}$ atom most probably occupies a staple position.

Cadmium and mercury were introduced by the Zhu group into preformed $\mathrm{Au}_{25}(\mathrm{SC} 2 \mathrm{Ph})_{18}{ }^{-}$by using a different approach in which the metal is added to the cluster solution as a thiolate, $\mathrm{Cd}(\mathrm{SC} 2 \mathrm{Ph})_{2}$ or $\mathrm{Hg}(\mathrm{SC} 2 \mathrm{Ph})_{2} \cdot{ }^{20}$ For $\mathrm{Cd}$, single-crystal X-ray crystallographic data indicated that doping occurred at the central position. As to $\mathrm{Hg}$, the cluster was concluded to have the same structure due to the same valence, NMR spectrum, and the loss of the same $\mathrm{M}_{1} \mathrm{Au}_{4}$ fragment in MALDI-TOF mass spectrometry. NMR was used only to rule out the possible presence of the tetraoctylammonium countercation, present in the native $\mathrm{Au}_{25}(\mathrm{SC} 2 \mathrm{Ph})_{18}{ }^{-}$solution. As for the metal-salt studies, ${ }^{21,23,24}$ the NMR spectrum showed a complex pattern. The outcome of the stepwise formation of trimetallic clusters, $\mathrm{MAg}_{\mathrm{x}} \mathrm{Au}_{24-\mathrm{x}}(\mathrm{SC} 2 \mathrm{Ph})_{18}$, was interpreted ${ }^{25}$ on the basis of the aforementioned conclusions on the central position eventually occupied by $\mathrm{Cd}$ or $\mathrm{Hg} .{ }^{20}$ Some doped clusters were prepared with ligands other than phenylethanethiol. In particular, Thanthirige et al. prepared $\mathrm{Au}_{24} \mathrm{M}(\mathrm{SC} 6)_{18}{ }^{0}(\mathrm{M}=\mathrm{Pt}$, $\mathrm{Hg}$ ) clusters by direct synthesis. Analysis of the MALDI-TOF mass spectrometry and X-ray photoelectron (XPS) spectra led to conclude that for both metals the doping occurred at the central position. ${ }^{15}$ The preparation and other properties of $\mathrm{Au}_{24} \mathrm{M}(\mathrm{SC} 6)_{18}{ }^{0}$ (M = Pt, Pd) were described by the Lee and Jiang groups in a previous publication. ${ }^{14}$ Negishi et al. used dodecanethiol to prepare $\mathrm{Au}_{24} \mathrm{Pd}(\mathrm{SC} 12)_{18}{ }^{0}$ and concluded, on the basis of experiments and density-functional theory (DFT) calculations that Pd occupies the center of the core. ${ }^{17,18}$

In a recent review article, ${ }^{8} \mathrm{Zhu}$ and co-workers concluded that "Doping specific number of heterometal atoms into specific positions of the nanocluster template is still one of the most challenging tasks in the nanofield." We could not agree more. Indeed, now the question is: How can we assign the specific position where these foreign-metal atoms actually go to? This is not just a problem per se, but also has far-reaching consequences because the results described above are consistently taken as the starting point for other investigations, whether related to different clusters or applications, as discussed in several review articles. ${ }^{5,7-9,11,25-28}$ Here we address this problem by specifically focusing on the doping with $\mathrm{Pt}$, $\mathrm{Pd}, \mathrm{Cd}$, and $\mathrm{Hg}$ atoms to form the corresponding $\mathrm{Au}_{24} \mathrm{M}(\mathrm{SR})_{18}{ }^{0}$ clusters. As aforementioned, conclusions on the specific location of the foreign-metal atom have been drawn mostly on the basis of the interpretation of single-crystal Xray crystallography and MALDI-TOF mass spectrometry data, sometimes with the support of DFT calculations, and results from XPS and UV-vis absorption spectroscopy. The structure of $\mathrm{Au}_{25}(\mathrm{SR})_{18}$, whether in the anionic or neutral form, ${ }^{29-31}$ is maintained in $\mathrm{Au}_{24} \mathrm{M}(\mathrm{SR})_{18}{ }^{0},{ }^{16,19,20,21,23}$ and shows that there are three possible positions for the $\mathrm{M}$ atom: center (c), icosahedron (i), and staples (s) (Figure 1a); whereas there is only one central atom, the other positions are of 12-fold equivalency.
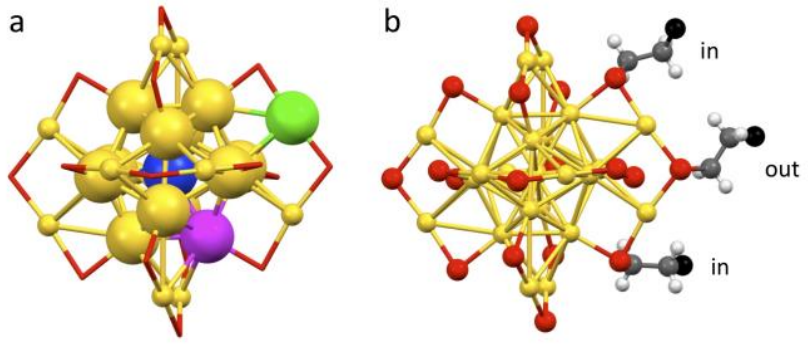

Figure 1. (a) Structure of $\mathrm{Au}_{25}(\mathrm{SR})_{18^{0 /-}}$ showing the three position types that can be occupied upon metal monodoping: central (blue), icosahedron (pink), and staple (green). The gold (yellow) and sulfur (red) atoms are shown, whereas the carbonaceous part of the ligands is omitted for clarity. (b) Structure of $\mathrm{Au}_{25}(\mathrm{SR})_{18^{0 /-}}$ showing the carbons (gray), hydrogens (white), and terminal groups (black) for both ligand types of one of the six staples.

Theoretical calculations have been performed to predict or explain the position of the heteroatom upon monometal doping, even ahead of substantial experimental work. Earlier DFT calculations by Jiang and Dai pointed to $\mathrm{Cd}$ and $\mathrm{Hg}$ as stable when in the center position. ${ }^{32}$ On the other hand, other DFT calculations carried out by Walter and Moseler predicted that Pd should be more stable when at the center, whereas for $\mathrm{Cd}$ the lowest energy isomer is at the icosahedron, rather than elsewhere. ${ }^{33}$ In a recent study, Taylor and Mpourmpakis used $^{34}$ their thermodynamic stability model (TSM), which attributes structure stability to a balance between the chemical potentials of the metal atoms in the core and the protecting shell, ${ }^{35}$ to describe doping effects on nanoclusters. The TSM predictions were concluded to be in excellent agreement with experiments. The case of $\mathrm{Hg}$ is particularly interesting. As we saw, $\mathrm{Hg}$ has been described as being at the center ${ }^{15,20}$ or in a staple position, ${ }^{23}$ with the latter considered ${ }^{34}$ as more likely and in agreement with the TSM. Although the icosahedral position, $\mathrm{Hg}(\mathrm{i})$, resulted close to the $95 \%$ prediction interval, a better proximity of the $\mathrm{Hg}$ (s) to the parity line (in a plot between shell-to-core bond energy and the metal-core cohesive energy) was seen as providing the first theoretical rationalization for the experimental observation of the $\mathrm{Hg}(\mathrm{s})$ position in $\mathrm{Au}_{24} \mathrm{Hg}(\mathrm{SR})_{18}{ }^{0}$. Regarding $\mathrm{Cd}$, which was also described that, depending of the synthetic method, could occupy two positions, center ${ }^{20}$ or icosahedron, ${ }^{21}$ the TSM results pointed to $\mathrm{Cd}(\mathrm{c})$ doping as being closer to the parity line than $\mathrm{Cd}(\mathrm{i})$ doping; thus, the authors also suggested that the latter could be potentially transformed into the former under proper experimental stimulus. Very recently, the Aikens group used DFT to study the doping process in a few clusters, including $\mathrm{Au}_{24} \mathrm{M}(\mathrm{SR}){ }_{18}{ }^{36}$ Whereas group $\mathrm{X}$ dopants $(\mathrm{Pd}, \mathrm{Pt})$ resulted stable when at the central position, for dopants in groups XI- XIII (and thus also for $\mathrm{Cd}$ and $\mathrm{Hg}$, group XII) the icosahedral position was found thermodynamically preferable mainly due to group theory and relativistic effects. As to the staple position compared to the central position, whereas for $\mathrm{Cd}$ the former has a slightly lower energy, for $\mathrm{Hg}$ the results point to $\mathrm{Hg}(\mathrm{c})$ as being quite more stable than $\mathrm{Hg}(\mathrm{s})$.

With the exception of Pt and Pd, for which there is no doubt that the direct synthesis yields a cluster monodoped at its central position, it is thus clear that for $\mathrm{Cd}$ and $\mathrm{Hg}$ available experimental data provide a number of opposite conclusions, possibly related to the specific synthetic method. DFT 
calculations have provided hints on this topic, though some analyses appear to be in contrast at least to some experimental conclusions. Here we use NMR spectroscopy, electrochemistry, MALDI-TOF, and single-crystal X-ray crystallography of each sample to demonstrate that in several cases the conclusions reached on the actual position of $\mathrm{Cd}$ and $\mathrm{Hg}$ atoms need to be drastically revised. Our study includes: (i) clusters protected by $\mathrm{SC} 4(\mathrm{Pt}, \mathrm{Pd}, \mathrm{Cd}, \mathrm{Hg})$ and the $\mathrm{SC} 2 \mathrm{Ph}(\mathrm{Cd}, \mathrm{Hg})$ as the ligands; (ii) direct synthesis ( $\mathrm{Pt}$, $\mathrm{Pd}$ ) and indirect synthetic methods, that is, metal exchange on both $\mathrm{Au}_{25}(\mathrm{SR})_{18}{ }^{-}(\mathrm{Cd}, \mathrm{Hg})$ and $\mathrm{Au}_{24} \mathrm{Cd}(\mathrm{SR})_{18}{ }^{0}(\mathrm{Hg})$; (iii) for $\mathrm{Cd}$ and $\mathrm{Hg}$ we used both the metal salt and the metal thiolate methods. This study is meant to provide new insights and perspectives into this general problem, and describe a possible experimental methodology to understand the actual doping location. The power of NMR spectroscopy and associated isotopic effects are especially highlighted. These results call for a warning about the reliability of conclusions based on mass-spectrometry fragmentation patterns and, especially, Xray crystallography of doped clusters.

\section{RESULTS AND DISCUSSION}

Synthesis. $\mathrm{Au}_{24} \mathrm{Pt}(\mathrm{SC} 4)_{18}{ }^{0}$ was prepared by reacting a solution of $\mathrm{HAuCl}_{4}$ and $\mathrm{H}_{2} \mathrm{PtCl}_{6}$ with the given thiol, followed by addition of $\mathrm{NaBH}_{4} \cdot{ }^{12} \mathrm{Au}_{24} \mathrm{Pt}(\mathrm{SC} 4)_{18}{ }^{0}$ could be purified from the main co-product, $\mathrm{Au}_{25}(\mathrm{SR})_{18}{ }^{-}$, according to the procedure described by Qian et al., ${ }^{12}$ in which $\mathrm{H}_{2} \mathrm{O}_{2}$ is used to cause degradation of the undoped cluster through multiple oxidation processes. For reasons that will be discussed in the $\mathrm{X}$-ray crystallography section, we used $n$-butanethiol. The synthesis of $\mathrm{Au}_{24} \mathrm{Pd}(\mathrm{SC} 4)_{18}{ }^{0}$ was carried out according to a very similar protocol, but for the use of $\mathrm{Na}_{2} \mathrm{PdCl}_{6}$ in place of $\mathrm{H}_{2} \mathrm{PtCl}_{6}$. Two $\mathrm{Au}_{25}(\mathrm{SR})_{18}{ }^{-}$clusters $(\mathrm{R}=\mathrm{C} 4, \mathrm{C} 2 \mathrm{Ph})$, which were prepared as already described, ${ }^{37-39}$ were allowed to react with $\mathrm{Cd}\left(\mathrm{NO}_{3}\right)_{2}$ or $\mathrm{Hg}\left(\mathrm{NO}_{3}\right)_{2}$, as described by the $\mathrm{Wu}$ group, ${ }^{21,23}$ and $\mathrm{Cd}(\mathrm{SR})_{2}$ or $\mathrm{Hg}(\mathrm{SR})_{2}$, as described by the $\mathrm{Zhu}$ group. ${ }^{20}$ These reactions are described in detail in the Experimental Section; we found that the same protocol works well for both $\mathrm{C} 4$ and $\mathrm{C} 2 \mathrm{Ph}$. In addition to using $\mathrm{Cd}\left(\mathrm{NO}_{3}\right)_{2}$ for making the thiolate, we used $\mathrm{CdCl}_{2}$, and the reactions went equally well. This check was expedient to then carry out the exchange reactions on $\mathrm{Au}_{25}(\mathrm{SR})_{18}{ }^{-}$clusters with ${ }^{113} \mathrm{Cd}(\mathrm{SR})_{2}$. Finally, on the two $\mathrm{Au}_{24} \mathrm{Cd}(\mathrm{SR})_{18}{ }^{0}$ clusters we exchanged $\mathrm{Cd}$ with $\mathrm{Hg}$, as described by the $\mathrm{Wu}$ group for $\mathrm{R}=\mathrm{C} 2 \mathrm{Ph} .{ }^{21}$ The clusters were carefully purified, recrystallized, and only afterward each sample batch was used for the NMR spectroscopy, UV-vis absorption spectroscopy (Figure 2 shows the SC4 series, whereas Figure S1 shows the SC2Ph series), MALDI-TOF mass spectroscopy, cyclic voltammetry $(\mathrm{CV})$, and differential pulse voltammetry (DPV) measurements. The synthetic methods used only yielded monodoped clusters. Most of them were also studied by single crystal X-ray crystallography. To check the quality of the results further, some of the crystals studied at the University of Jyväskylä were also studied at the University of Padova.

$\mathrm{Au}_{24} \mathbf{P t}(\mathrm{SC} 4)_{18^{0}}{ }^{0}$ and $\mathbf{A u}_{24} \mathbf{P d}(\mathrm{SC} 4)_{18}{ }^{0}$. For both platinum and palladium, the direct synthesis of $\mathrm{Au}_{24} \mathrm{M}(\mathrm{SR})_{18}{ }^{0}$ ( $\mathrm{R}=$ $\mathrm{C} 2 \mathrm{Ph}, \mathrm{C} 6, \mathrm{C} 12)$ has been consistently described to yield clusters doped at the center. ${ }^{12-19}$ For $\mathrm{R}=\mathrm{C} 4$, we followed the same synthetic and purification protocol described for platinum by Qian et al. ${ }^{12}$ and adapted for palladium by Kwak et al.. ${ }^{14}$ MALDI-TOF mass spectrometry clearly indicated that the purified clusters only contain one foreign-metal atom, as shown in Figure $\mathrm{S} 2$ for $\mathrm{Au}_{24} \mathrm{Pt}(\mathrm{SC} 4)_{18}{ }^{0}$, and no contamination from residual $\mathrm{Au}_{25}(\mathrm{SC} 4)_{18}{ }^{-}$or $\mathrm{Au}_{25}(\mathrm{SC} 4)_{18}{ }^{0}$.

The NMR behaviors of $\mathrm{Au}_{24} \mathrm{Pt}(\mathrm{SC} 4)_{18}{ }^{0}$ and $\mathrm{Au}_{24} \mathrm{Pd}(\mathrm{SC} 4)_{18}{ }^{0}$ were studied in $\mathrm{C}_{6} \mathrm{D}_{6}$, at $1.5-2.1 \mathrm{mM}$ concentration of the cluster, and the chemical shifts $(\delta)$ are referred to tetramethylsilane; these conditions were the same also for all other clusters studied. Beside the monodimensional ${ }^{1} \mathrm{H}$ NMR spectra, the clusters were studied by ${ }^{1} \mathrm{H},{ }^{1} \mathrm{H}$-homonuclear correlation spectroscopy (COSY) and ${ }^{1} \mathrm{H},{ }^{13} \mathrm{C}$-heteronuclear multiple quantum coherence (HMQC) spectroscopy. The 2D spectra, whose analysis allowed assigning all resonances, are provided in Figures S3-S5, whereas Table S1 gathers all chemical shift values. $\mathrm{Au}_{24} \mathrm{Pt}(\mathrm{SC} 4)_{18}{ }^{0}$ and $\mathrm{Au}_{24} \mathrm{Pd}(\mathrm{SC} 4)_{18}{ }^{0}$ are diamagnetic, neutral species ${ }^{16}$ and are thus directly comparable with the diamagnetic anion $\left[\mathrm{Au}_{25}(\mathrm{SC} 4)_{18}{ }^{-}\right](n-$ $\left.\mathrm{Oct}_{4} \mathrm{~N}\right)^{+}$(where $n$-Oct stands for norm-octyl), whose NMR data $^{37,38}$ are also provided in Table S1.

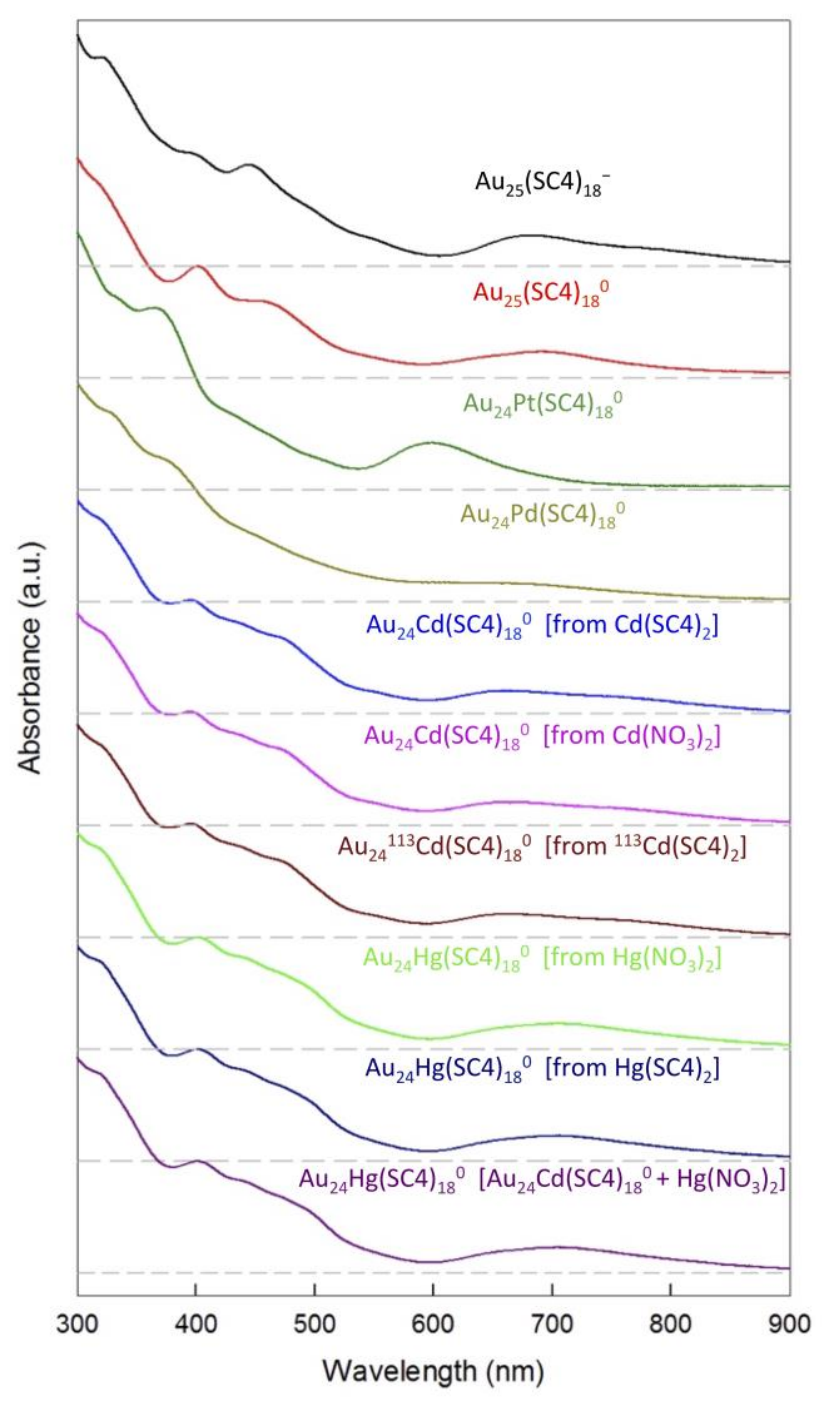

Figure 2. UV-vis absorption spectra of all SC4 samples $(0.2 \mathrm{mM}$, $1 \mathrm{~mm}$ cuvette) in $\mathrm{CH}_{2} \mathrm{Cl}_{2}$. For the sake of better comparison, the curves have been shifted vertically. The dashed lines mark the corresponding zero absorbance.

$\mathrm{Au}_{25}$ and monodoped clusters are known to share the same structural features: a central $\mathrm{Au}$ atom, $12 \mathrm{Au}$ atoms forming an icosahedron, and an external shell composed of six $-(\mathrm{SR})_{\mathrm{in}}{ }^{-}$ 
$\mathrm{Au}-(\mathrm{SR})_{\mathrm{out}}-\mathrm{Au}-(\mathrm{SR})_{\mathrm{in}}-$ double staples. Each staple consists of two inner thiolates (in) and one outer thiolate (out) (Figure 1b). The term inner indicates that the two SR groups also bind to the icosahedron $\mathrm{Au}$ atoms, whereas outer indicates that the SR group is at the outmost position of the double staple. In $\left[\mathrm{Au}_{25}(\mathrm{SC} 4)_{18}{ }^{-}\right]\left(n-\mathrm{Oct}_{4} \mathrm{~N}\right)^{+},{ }^{37,38}$ the two ligand types have different $\delta$ values, well-defined signals (corresponding to the methylene groups in positions $\alpha, \beta$, and $\gamma$ with respect to sulfur, and the methyl group in position $\delta$ ), and for the same resonance the integrals are in the 2:1 ratio expected for the 12 inner and 6 outer ligands. The spectra of $\mathrm{Au}_{24} \mathrm{Pt}(\mathrm{SC} 4)_{18}{ }^{0}$ and $\mathrm{Au}_{24} \mathrm{Pd}(\mathrm{SC} 4)_{18}{ }^{0}$ exhibit exactly the same general features, but for slightly different chemical-shift values (Table S1). Figure 3 shows the comparison between the Pt-doped and the undoped clusters. This behavior clearly indicates that the symmetry of the ligands of the parent $\mathrm{Au}_{25}(\mathrm{SC} 4)_{18}{ }^{-}$cluster is preserved upon monodoping, as also discussed for $\mathrm{R}=\mathrm{C} 2 \mathrm{Ph}$ by Qian et al. ${ }^{12}$ and later by Tian et al. ${ }^{16}$ For both Pt and Pd, the ${ }^{1} \mathrm{H}$ NMR spectra of $\mathrm{Au}_{24} \mathrm{M}(\mathrm{SC} 4)_{18}{ }^{0}$ can thus be taken as representing the blueprint of the typical "uncomplicated" NMR behavior expected for a $\mathrm{Au}_{24} \mathrm{M}(\mathrm{SC} 4)_{18}{ }^{0}$ cluster doped in its central position.

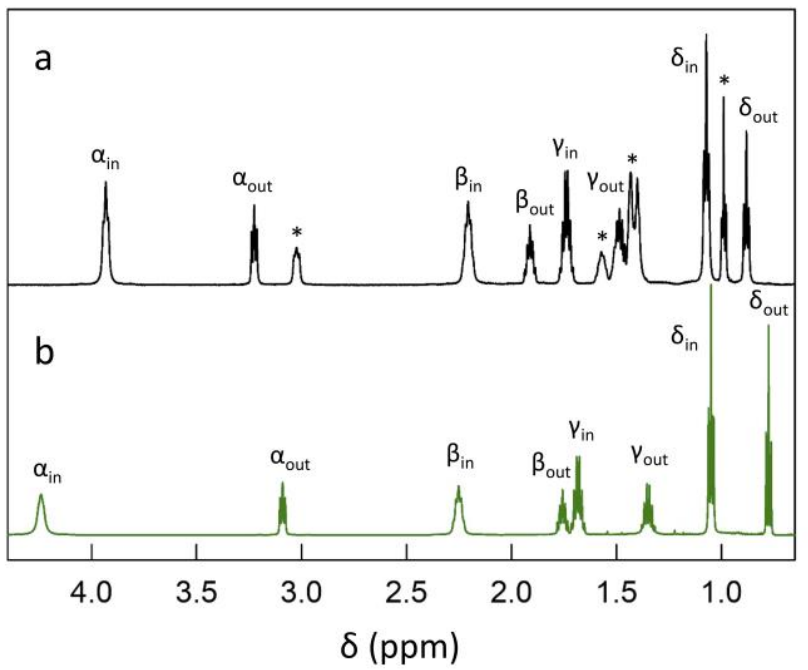

Figure 3. ${ }^{1} \mathrm{H}$ NMR spectra of (a) $\left[n-\mathrm{Oct}_{4} \mathrm{~N}^{+}\right]\left[\mathrm{Au}_{25}(\mathrm{SC} 4)_{18}{ }^{-}\right]$and (b) $\mathrm{Au}_{24} \mathrm{Pt}(\mathrm{SC} 4)_{18}{ }^{0}$. The peaks marked with a star pertain to $n$ Oct $4 \mathrm{~N}^{+}$. Both samples were in $\mathrm{C}_{6} \mathrm{D}_{6}$ at $25^{\circ} \mathrm{C}$.

Au24Hg(SC4)18 ${ }^{0}$. The mercury-doped clusters were prepared according to three previously published methods (for $\mathrm{C} 2 \mathrm{Ph}$ ), i.e., by the (i) Au-exchange reaction of $\mathrm{Au}_{25}(\mathrm{SC} 4)_{18}$ with $\mathrm{Hg}(\mathrm{SR})_{2}$ (Wang et al. $)^{20}$ and (ii) $\mathrm{Hg}\left(\mathrm{NO}_{3}\right)_{2}$ (Liao et al.), ${ }^{23}$ and by the (iii) Cd-exchange reaction of $\mathrm{Au}_{24} \mathrm{Cd}(\mathrm{SC} 4)_{18}{ }^{0}$ with $\mathrm{Hg}\left(\mathrm{NO}_{3}\right)_{2}$ (Yao et al.). ${ }^{21}$ After purification and recrystallization, all three methods led to obtain very pure $\mathrm{Au}_{24} \mathrm{Hg}(\mathrm{SC} 4)_{18}{ }^{0}$ samples. The UV-vis absorption spectroscopy and MALDI-TOF spectra are shown in Figures 2 and S6, respectively.

We first consider the $\mathrm{Au}_{24} \mathrm{Hg}(\mathrm{SC} 4)_{18}{ }^{0}$ sample prepared from $\mathrm{Hg}(\mathrm{SR})_{2}$. Figure 4 shows its ${ }^{1} \mathrm{H}$ NMR spectrum and identification of the signals, as achieved by analysis of the COSY and total correlation spectroscopy (TOCSY) spectra

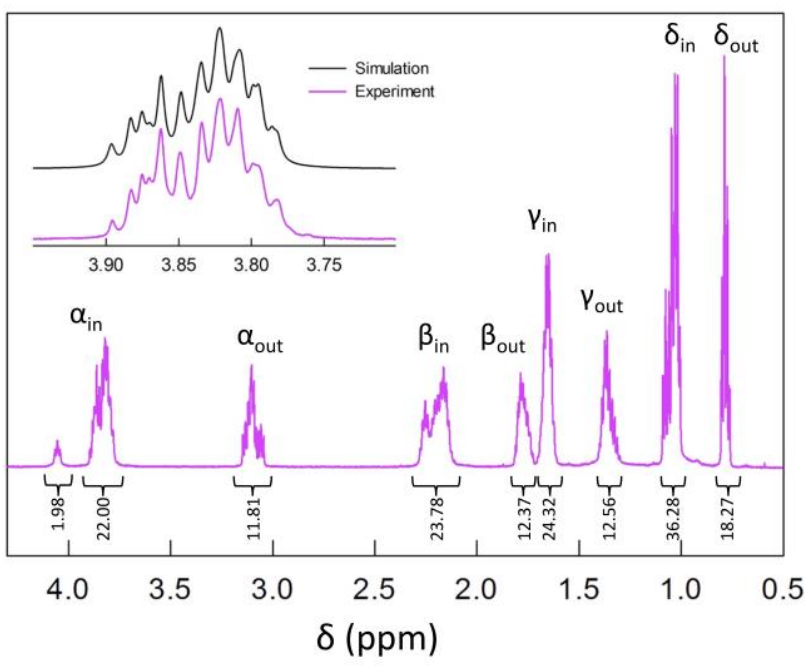

Figure 4. ${ }^{1} \mathrm{H}$ NMR spectra of $2.1 \mathrm{mM} \mathrm{Au} 24 \mathrm{Hg}(\mathrm{SC} 4)_{18}{ }^{0}$ in $\mathrm{C}_{6} \mathrm{D}_{6}$ at $25{ }^{\circ} \mathrm{C}$. The Greek symbols have the usual meaning. The inset shows an enlarged part of the spectral region (experiment and simulation) pertaining to $11 \alpha-\left(\mathrm{CH}_{2}\right)_{\text {in }}$ resonances. Integrals refer to the number of protons.

(Figures S7 and S8); the integrals, carried out in the ranges indicated, are in a 2:1 ratio, as expected for the inner relative to the outer resonances. Figure 4 clearly shows that for this cluster the ligand symmetry is completely removed. Table S2 gathers all ${ }^{1} \mathrm{H}$ and ${ }^{13} \mathrm{C}$ chemical shifts. Perturbations from the simple pattern exhibited by the undoped cluster (Figure 3a) are seen for all resonances and are especially evident for the inner ligands and the protons nearer to the cluster core. It is noteworthy that signal complexity is observed even for the $\delta$ $\left(\mathrm{CH}_{3}\right)_{\text {out }}$ proton resonance, which, being the most distant from the core, in all gold nanocluster previously investigated ${ }^{3}$ has always been the least sensitive to core size, charge, magnetic state, and environmental effects. The $\alpha-\left(\mathrm{CH}_{2}\right)_{\text {in }}$ and $\alpha-\left(\mathrm{CH}_{2}\right)_{\text {out }}$ resonances, which are at 4.07-3.78 and 3.15-3.05 ppm, respectively, exhibit particularly complex patterns. In particular, one of the $\alpha-\left(\mathrm{CH}_{2}\right)_{\text {in }}$ triplets (with an integral value corresponding to one ligand) is clearly separated from the others. It is also worth noticing that this lack of symmetry does not induce diastereotopic effects in the ligands, as opposed to what found for achiral ligands in the presence of interligand interactions and/or when the staple arrangement is chiral $\left(\mathrm{Au}_{38}(\mathrm{SR})_{24}{ }^{0}\right.$ and $\left.\mathrm{Au}_{144}(\mathrm{SR})_{60}{ }^{0}\right){ }^{40-42}$ Regarding the complexity of the proton signals for both the inner and outer ligands (see below), a quite similar behavior is also exhibited by the corresponding ${ }^{13} \mathrm{C}$ resonances and ${ }^{13} \mathrm{C}$ chemical shift values (HMQC experiments, Figure S9). In particular, for one of $\alpha-\left(\mathrm{CH}_{2}\right)_{\text {in }}$ carbons, which corresponds to the isolated ${ }^{1} \mathrm{H}$ triplet at $4.055 \mathrm{ppm}$, the ${ }^{13} \mathrm{C}$ chemical shift value is distinctly smaller $(37.25 \mathrm{ppm})$ than the similar values shown by the other 11 ligands (39.01-38.79 ppm). A few differences are also detected for the $\beta-\left(\mathrm{CH}_{2}\right)_{\text {in }}, \gamma-\left(\mathrm{CH}_{2}\right)_{\text {in }}$, and $\delta-\left(\mathrm{CH}_{3}\right)_{\text {in }}{ }^{13} \mathrm{C}$ resonances. Small differences are also present in the $\alpha$ $\left(\mathrm{CH}_{2}\right)_{\text {out }}$ and $\gamma-\left(\mathrm{CH}_{2}\right)_{\text {out }}$ resonances, whereas $\beta-\left(\mathrm{CH}_{2}\right)_{\text {out }}$ and $\delta$ $\left(\mathrm{CH}_{3}\right)_{\text {out }}$ appear isochronous.

Regarding the number of different inner ligands detectable in the ${ }^{1} \mathrm{H}$ NMR spectrum, we took advantage of the net separation of the $\alpha-\left(\mathrm{CH}_{2}\right)_{\text {in }}$ triplet at $4.055 \mathrm{ppm}$ to simulate the cumulative signal pertaining to the remaining 11 inner 
resonances. By using the intensity of the isolated triplet as the starting point, we generated the convoluted signal by assigning and optimizing the chemical shifts of the 11 triplets. The indent in Figure 4 shows the satisfactory outcome of the simulation. The individual chemical shifts (the number of isochronous signals is given in parenthesis) are at $3.883(1)$, 3.862 (2), 3.834 (1), 3.823 (4), 3.805 (1), 3.798 (1), and 3.794 (1) $\mathrm{ppm}$.

A very similar set of results was obtained by analysis of the TOCSY spectrum (Figure S8): 3.883 (1), 3.854 (2), 3.818 (3), 3.808 (3), 3.786 (2) ppm. Despite small differences between the two methods, these results show that the perturbation caused by replacing one single $\mathrm{Au}$ atom with $\mathrm{Hg}$ generates at least 6 subgroups in the $\alpha-\left(\mathrm{CH}_{2}\right)_{\text {in }}$ resonances. Regarding the $\alpha-\left(\mathrm{CH}_{2}\right)_{\text {out }}$ triplets, analysis of the TOCSY spectrum shows that the complex signal at ca. $3.1 \mathrm{ppm}$ is composed by 6 distinguishable triplets: 3.147 (1), 3.134 (1), 3.129 (1), 3.109 (1), 3.087 (1), and 3.053 (1) ppm. It is noteworthy that the effect of $\mathrm{Hg}$ is so strong that even all other inner and outer resonance types are affected. The ${ }^{1} \mathrm{H}$ and ${ }^{13} \mathrm{C}$ data are collected in Table S2.

Overall, these results clearly show that $\mathrm{Hg}$ cannot be located in the center of the cluster, as previously proposed for $\mathrm{R}=\mathrm{C} 2 \mathrm{Ph} \cdot{ }^{20}$ On the other hand, the above NMR data cannot conclude whether $\mathrm{Hg}$ is in one of the icosahedral vertexes or one of the staples.

The second sample investigated was prepared from $\mathrm{Hg}\left(\mathrm{NO}_{3}\right)_{2}$, according to the method described by Liao et al.. ${ }^{23}$ It should be recalled that this method was described to yield an $\mathrm{Hg}(\mathrm{s})$ doped cluster, though starting from a different ligand $(\mathrm{R}=\mathrm{C} 2 \mathrm{Ph})$. The ${ }^{1} \mathrm{H}$ NMR spectrum (Figure S10), associated 2D spectra, and integral values of recrystallized cluster are identical to those just described for the first sample.

In the third synthetic method, we prepared $\mathrm{Au}_{24} \mathrm{Cd}(\mathrm{SC} 4)_{18}{ }^{0}$ (thiolate method, as described in the next section) and then reacted it with $\mathrm{Hg}\left(\mathrm{NO}_{3}\right)_{2}$ according to the protocol described for $\mathrm{R}=\mathrm{C} 2 \mathrm{Ph}$ by the $\mathrm{Wu}$ group. ${ }^{21}$ The reaction proceeded rapidly $(<10 \mathrm{~min})$ and efficiently ( $90 \%$ yield). Once again, the ${ }^{1} \mathrm{H}$ NMR spectrum of the crystalline product turned out to be identical to those recorded for the other two samples (Figure S10). The spectrum of this specific sample was also tested for stability and found to be perfectly reproducible after 4 weeks at $10{ }^{\circ} \mathrm{C}$.

It is finally noteworthy that all three samples gave the same fragmentation pattern in MALDI-TOF mass spectrometry (Figure S6) and identical UV-vis absorption spectra (Figure 2). Their electrochemical behavior will be discussed later.

As NMR is an extremely sensitive tool to detect even minor differences in molecular properties and chemical environment effects, ${ }^{3}$ the results obtained for the three samples allow us to conclude that: (i) the specific synthetic approach, including the indirect method, does not yield clusters doped at different positions; (ii) mercury does not dope the cluster at the central position. At this stage, whether the three identical samples consist of $\mathrm{Hg}(\mathrm{s})$ or $\mathrm{Hg}$ (i) remains to be understood.

$\mathbf{A u}_{24} \mathbf{C d}(\mathbf{S C} 4)_{18}{ }^{0}$. The cadmium-doped clusters were prepared in three ways. The first two methods are based on the use of (i) $\mathrm{Cd}(\mathrm{SR})_{2}$, obtained upon reaction of $\mathrm{Cd}\left(\mathrm{NO}_{3}\right)_{2}$ with the thiol (Wang et al.), ${ }^{20}$ or (ii) $\mathrm{Cd}\left(\mathrm{NO}_{3}\right)_{2}$ (Yao et al.). ${ }^{21}$. The third approach consists in using $\mathrm{CdCl}_{2}$ or ${ }^{113} \mathrm{CdCl}_{2}$ (instead of $\left.\mathrm{Cd}\left(\mathrm{NO}_{3}\right)_{2}\right)$ to make the thiolate. Figure 5a shows the typical

${ }^{1} \mathrm{H}$ NMR spectrum of the purified, recrystallized cluster obtained according to the $\mathrm{Cd}\left(\mathrm{NO}_{3}\right)_{2}$ method. Regardless of the synthetic procedure, however, the ${ }^{1} \mathrm{H}$ NMR spectra are identical (Figure S11). As for the $\mathrm{Hg}$ case, the ${ }^{1} \mathrm{H}$ NMR spectra show that the ligand symmetry is removed. The various signal types (position along the ligand chain and ligand type) were attributed through TOCSY analysis. The $\alpha$ $\left(\mathrm{CH}_{2}\right)_{\text {in }}$ and $\alpha-\left(\mathrm{CH}_{2}\right)_{\text {out }}$ resonances at 3.93-3.67 and 3.16-3.03 ppm, respectively, exhibit a complex pattern qualitatively similar to that of the $\mathrm{Hg}$-doped clusters. Main differences are: (i) one of the $\alpha-\left(\mathrm{CH}_{2}\right)_{\text {in }}$ is separated from the others but is seen at higher fields (at $3.716 \mathrm{ppm}$ ); (ii) the separation of one of the $\alpha-\left(\mathrm{CH}_{2}\right)_{\text {out }}$ resonances (at $3.052 \mathrm{ppm}$ ) is more evident than for the $\mathrm{Hg}$ case. The integrals (Figure 5a) of the various inner and outer resonances are also in a 2:1 ratio.

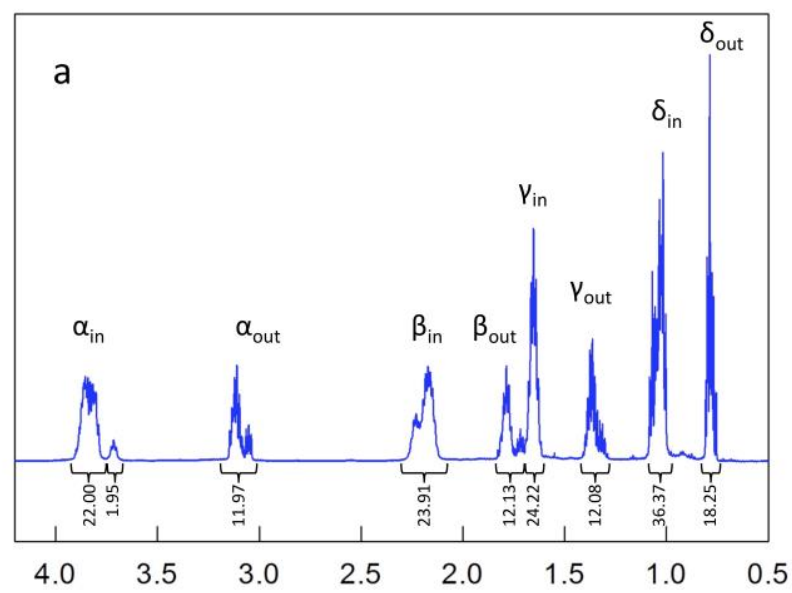

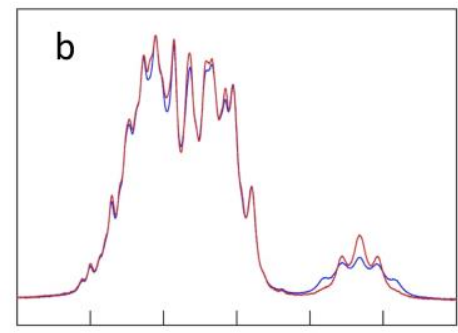

$\begin{array}{lllll}3.90 & 3.85 & 3.80 & 3.75 & 3.70\end{array}$

\section{$\delta(\mathrm{ppm})$}

Figure 5. (a) ${ }^{1} \mathrm{H}-\mathrm{NMR}$ spectrum of $2.1 \mathrm{mM} \mathrm{Au} 24 \mathrm{Cd}(\mathrm{SC} 4)_{18}{ }^{0}$ prepared from $\mathrm{Cd}\left(\mathrm{NO}_{3}\right)_{2}$ in $\mathrm{C}_{6} \mathrm{D}_{6}$ at $25{ }^{\circ} \mathrm{C}$. Integrals refer to the number of protons. Graphs (b) and (c) refer to the $\alpha-\left(\mathrm{CH}_{2}\right)_{\text {in }}$ and $\alpha-\left(\mathrm{CH}_{2}\right)_{\text {out }}$ regions, respectively, for $2.1 \mathrm{mM} \mathrm{Au} 24 \mathrm{Cd}(\mathrm{SC} 4)_{18}{ }^{0}$ (red) and $2.1 \mathrm{mM} \mathrm{Au} 24^{113} \mathrm{Cd}(\mathrm{SC} 4)_{18}{ }^{0}$ (blue); the latter was prepared using the thiolate obtained from ${ }^{113} \mathrm{CdCl}_{2}$.

The ${ }^{1} \mathrm{H}$ and ${ }^{13} \mathrm{C}$ data (Table S3) show very similar patterns as observed for the Hg-doped clusters. According to the TOCSY spectrum, the $12 \alpha-\left(\mathrm{CH}_{2}\right)_{\text {in }}$ triplets are at 3.865 (2), 3.834 (6), 3.826 (2), 3.803 (1), and 3.716 (1) ppm, whereas the $6 \alpha-\left(\mathrm{CH}_{2}\right)_{\text {out }}$ triplets are at $3.126(1), 3.122(1), 3.108$ (3), and 3.052 (1) $\mathrm{ppm}$. Differences are also seen along the ligand chain for both inner and outer ligands. Regarding ${ }^{13} \mathrm{C}$, some differences are seen for $\alpha-\left(\mathrm{CH}_{2}\right)_{\text {in }}$ (whereas 11 ligands are at $38.2 \pm 0.2 \mathrm{ppm}$, the isolated ligand in at $34.15 \mathrm{ppm}), \beta-$ $\left(\mathrm{CH}_{2}\right)_{\text {in }}, \delta-\left(\mathrm{CH}_{3}\right)_{\text {in, }}, \alpha-\left(\mathrm{CH}_{2}\right)_{\text {out }}$, and $\beta-\left(\mathrm{CH}_{2}\right)_{\text {out }}$; for $\gamma\left(\mathrm{CH}_{2}\right)_{\text {in }}, \gamma-$ 
$\left(\mathrm{CH}_{2}\right)_{\text {out }}$, and $\delta-\left(\mathrm{CH}_{3}\right)_{\text {out }}$, differences are undetectable or within experimental error.

We also note that the NMR pattern of the Cd-doped clusters does not show any diastereotopic effect, i.e., the protons of each $\mathrm{CH}_{2}$ in each ligand type and ligand subgroup are equivalent (as already noted for the $\mathrm{Hg}$-doped cluster). It is finally worth stressing that all three samples gave the same fragmentation pattern in MALDI-TOF mass spectrometry (Figure S12) and identical UV-vis absorption spectra (Figure 2). The electrochemical behavior will be discussed later.

To conclude, analysis of the three $\mathrm{Au}_{24} \mathrm{Cd}(\mathrm{SC} 4)_{18}{ }^{0}$ samples shows that: (i) independently of the synthetic method doping always occurs at the same position and (ii) this position is not at the center of the cluster.

The question now is: is $\mathrm{Cd}$ on the icosahedron, as inferred by $\mathrm{Wu}$ and co-workers for $\mathrm{SC} 2 \mathrm{Ph},{ }^{21}$ or in one of the staples? To address this problem, we resorted to carry out the $\mathrm{Cd}(\mathrm{SR})_{2}$ synthesis by starting from ${ }^{113} \mathrm{CdCl}_{2}$. Whereas the natural abundance of ${ }^{113} \mathrm{Cd}$ in $\mathrm{Cd}$ samples is $12.23 \%$, enriched ${ }^{113} \mathrm{Cd}$ samples contain $95 \%$ of this spin $1 / 2$ isotope. A point-by-point comparison between the ${ }^{1} \mathrm{H}$ NMR spectra of $\mathrm{Au}_{24}{ }^{113} \mathrm{Cd}(\mathrm{SC} 4)_{18}{ }^{0}$ and $\mathrm{Au}_{24} \mathrm{Cd}(\mathrm{SC} 4)_{18}{ }^{0}$ (both obtained from the thiolate method) shows (Figure S13) that the effect of the isotopic enrichment is observed only for the signal at 3.716 ppm, while the rest of the spectrum is completely unchanged. Figure $5 b$ shows a detail of the only change detected. In particular, the small bumps around the isolated $\alpha-\left(\mathrm{CH}_{2}\right)_{\text {in }}$ triplet of $\mathrm{Au}_{24} \mathrm{Cd}(\mathrm{SC} 4)_{18}{ }^{0}$ are significantly enhanced in $\mathrm{Au}_{24}{ }^{113} \mathrm{Cd}(\mathrm{SC} 4)_{18}{ }^{0}$, in agreement with the ca. 8-fold isotopic enrichment. Conversely, the isolated and the other 5 convoluted $\alpha-\left(\mathrm{CH}_{2}\right)_{\text {out }}$ triplets are identical (Figure $5 \mathrm{c}$ ).

${ }^{1} \mathrm{H}-{ }^{1} \mathrm{H}$ homodecoupling experiments were carried out by applying a standard pulse sequence. Decoupling was performed at the frequency of the $\beta-\left(\mathrm{CH}_{2}\right)_{\text {in }}$ signal $(2.173$ $\mathrm{ppm})$ that exhibits a scalar correlation with the isolated $\alpha$ $\left(\mathrm{CH}_{2}\right)_{\text {in }}$ signal at $3.716 \mathrm{ppm}$. Figure 6 shows the main details of the effects observed for the $\mathrm{Au}_{24}{ }^{113} \mathrm{Cd}(\mathrm{SC} 4)_{18}{ }^{0}$ and $\mathrm{Au}_{24} \mathrm{Cd}(\mathrm{SC} 4)_{18}{ }^{0}$ samples. As expected on the basis of the ${ }^{1} \mathrm{H}-$ ${ }^{113} \mathrm{Cd}$ coupling, whereas the enriched cluster shows a doublet (Figures 6a), the latter yields a singlet (Figure 6b), though accompanied by traces of a doublet (due to the presence of ${ }^{113} \mathrm{Cd}$ and ${ }^{111} \mathrm{Cd}$, which is another spin $1 / 2$ isotope with a natural abundance of $12.80 \%$ ). The doublet in Figure 6a allows determining a ${ }^{3} \mathrm{~J}\left({ }^{1} \mathrm{H}-{ }^{113} \mathrm{Cd}\right)$ coupling constant of 14.3(0.1) Hz. For both $\mathrm{Au}_{24}{ }^{113} \mathrm{Cd}(\mathrm{SC} 4)_{18}{ }^{0}$ and $\mathrm{Au}_{24} \mathrm{Cd}(\mathrm{SC} 4)_{18}{ }^{0}$, the same pulse sequence applied to the isolated $\beta-\left(\mathrm{CH}_{2}\right)_{\text {out }}$ signal $(1.719 \mathrm{ppm})$, which correlates with the corresponding isolated $\alpha-\left(\mathrm{CH}_{2}\right)_{\text {out }}$ signal at $3.052 \mathrm{ppm}$, transforms the latter into a sharp singlet, as could be anticipated on the basis of the uncomplicated shape of this triplet (Figures 6c,d). The slightly different position of the peaks in the decoupled spectra is due to the Bloch-Siegert shift, which causes resonances to move away from the decoupling frequency.

Figure 7a shows two models of the possible positions occupied by $\mathrm{Cd}$. For $\mathrm{Cd}(\mathrm{s})$, the bond sequence from $\mathrm{Cd}$ to the $\alpha-\left(\mathrm{CH}_{2}\right)_{\text {in }}$ and $\alpha-\left(\mathrm{CH}_{2}\right)_{\text {out }}$ protons is the same, H-C-S-Cd, whereas for $\mathrm{Cd}(\mathrm{i})$ the distance from the $\alpha-\left(\mathrm{CH}_{2}\right)_{\text {out }}$ protons is larger by two bonds (H-C-S-Au-S-Cd bond sequence) than for the $\alpha-\left(\mathrm{CH}_{2}\right)_{\text {in }}$ protons. It is thus conceivable that for $\mathrm{Cd}(\mathrm{i})$ doping only the $\alpha-\left(\mathrm{CH}_{2}\right)_{\text {in }}$ protons are affected, as the experiments indeed indicate. On the other hand, if the

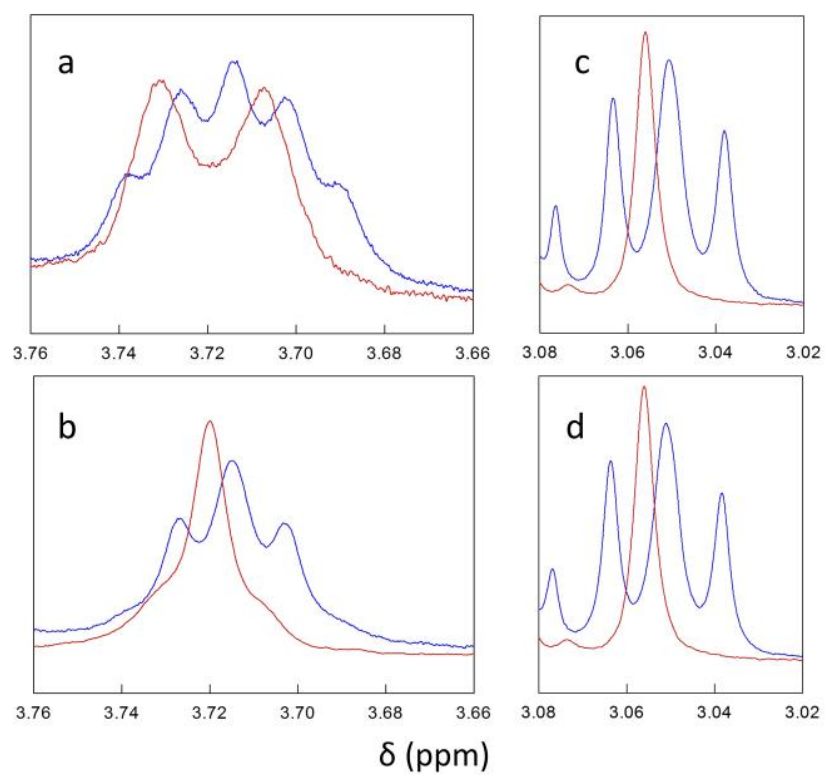

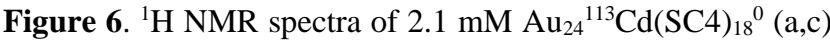
and $2.1 \mathrm{mM} \mathrm{Au} 24 \mathrm{Cd}(\mathrm{SC} 4)_{18}(\mathrm{~b}, \mathrm{~d})$ focusing on the $\alpha-\left(\mathrm{CH}_{2}\right)_{\text {in }}$ $(\mathrm{a}, \mathrm{b})$ and $\alpha-\left(\mathrm{CH}_{2}\right)_{\text {out }}(\mathrm{c}, \mathrm{d})$ regions. The spectra are shown before (blue traces) and after ${ }^{1} \mathrm{H}-{ }^{1} \mathrm{H}$ homodecoupling (red traces). $\mathrm{C}_{6} \mathrm{D}_{6}, 25^{\circ} \mathrm{C}$.
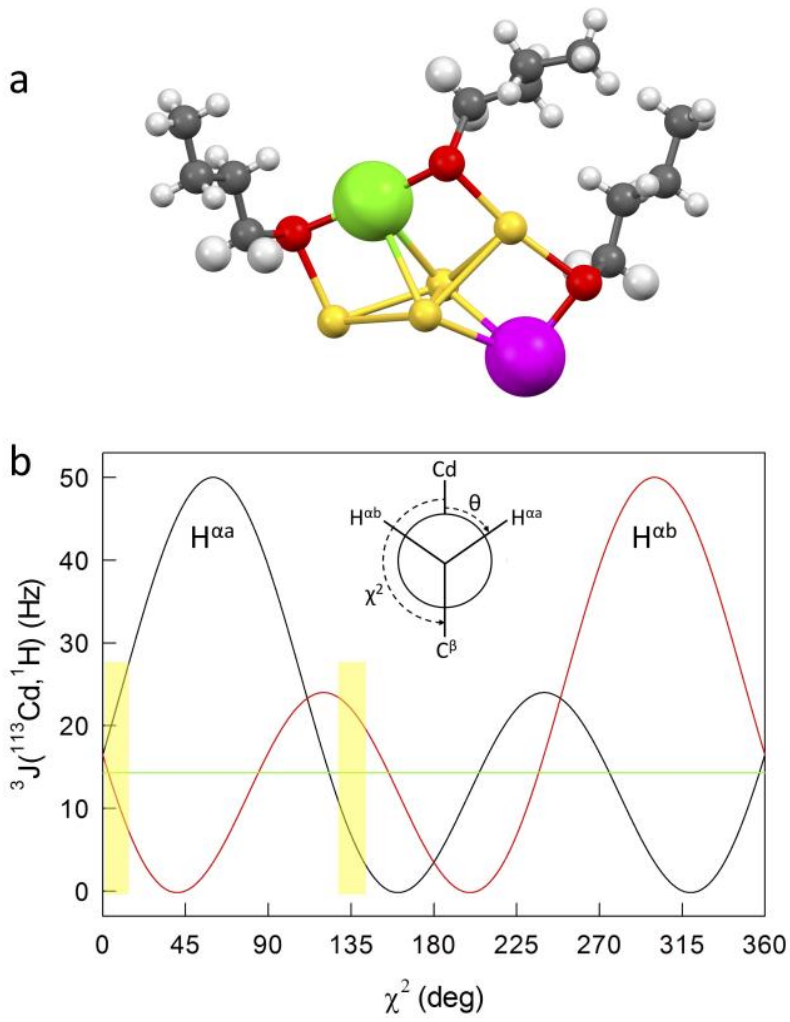

Figure 7. (a) Models of the possible positions occupied by Cd. (b) Karplus-like correlation of the ${ }^{3} J\left({ }^{1} \mathrm{H}_{-}{ }^{113} \mathrm{Cd}\right)$ coupling constant as a function of the dihedral angle $\chi^{2}$. The Newman projection of the investigated bond sequence illustrates the relationship between the $\chi^{2}$ and $\theta$ dihedral angles. The areas highlighted in yellow show the regions where the average ${ }^{3} J\left({ }^{1} \mathrm{H}^{113} \mathrm{Cd}\right)$ coupling constant values are compatible with the experimentally determined $J$ value. 
exchange yields $\mathrm{Cd}(\mathrm{s}),{ }^{113} \mathrm{Cd}$ would have affected both the $\alpha$ $\left(\mathrm{CH}_{2}\right)_{\text {in }}$ and $\alpha-\left(\mathrm{CH}_{2}\right)_{\text {out }}$ protons with equal probability, which is in contrast to the experimental outcome.

To gain more quantitative insights into this aspect, we propose the use of a Karplus-type correlation, which was originally developed to describe the dihedral angle dependence of three bond ${ }^{1} \mathrm{H}-{ }^{1} \mathrm{H}$ coupling. ${ }^{43}$ In 1994 , Vašák and co-workers could demonstrate that a Karplus-type correlation describes nicely also the dihedral angle dependence of the three bond ${ }^{113} \mathrm{Cd}-{ }^{1} \mathrm{H}$ coupling, as obtained from HMQC data for $\mathrm{Cd}$-substituted metalloproteins in comparison with the crystal structure data. ${ }^{44,45}$ The correlation was observed for the cysteine H-C-S-Cd dihedral angle. The same group could previously demonstrate that the $\mathrm{Cd}$ derivative is isostructural with the native protein. ${ }^{46}$ Vašák and co-workers concluded that although heteronuclear couplings involving heavy nuclei generally depend on orbital angular momentum, electron-nucleus dipole-dipole interaction, and Fermi contact contributions, for Cd-substituted metalloproteins the dihedral angle is the principal determinant of the Fermi contact term and the dominant variable. Figure $7 \mathrm{~b}$, which is adapted from the original work, ${ }^{44,45,47}$ illustrates the dependence of the ${ }^{3} \mathrm{~J}\left({ }^{1} \mathrm{H}-{ }^{113} \mathrm{Cd}\right)$ coupling constant on the dihedral angle $\theta,{ }^{3} J\left({ }^{1} \mathrm{H}^{113} \mathrm{Cd}\right)=36\left(\cos ^{2} \theta\right)-13(\cos \theta)+1$, with $r^{2}=98.7 \%$ and confidence limits of ca. $10 \mathrm{~Hz}$; tetrahedral geometry around $\mathrm{C}^{\beta}$ is assumed. More precisely, Figure $7 \mathrm{~b}$ shows the correlation as a function of $\chi^{2}$, which refers to the dihedral angle with respect to the $\beta$ carbon atom. The inset to Figure $7 \mathrm{~b}$ shows the Newman projection of the bond sequence and defines the relationship between the dihedral angles $\theta$ and $\chi^{2}$, where $\theta$ relates to $\mathrm{H}^{\mathrm{a}}$ (one of the two $\alpha-\left(\mathrm{CH}_{2}\right)_{\text {in }}$ protons $)$. The correlation shows that a coupling constant should be detected no matter the magnitude of $\theta$ or $\chi^{2}$, as at least one of the two protons $\left(\mathrm{H}^{\mathrm{a}}\right.$ and $\left.\mathrm{H}^{\mathrm{b}}\right)$ always provides a finite coupling value. Regarding our Cd-doped clusters, the Karplus-type correlation thus confirms that for the hypothetical $\mathrm{Cd}(\mathrm{s})$ some coupling with the $\alpha-\left(\mathrm{CH}_{2}\right)_{\text {out }}$ protons should be observed as well as with the $\alpha-\left(\mathrm{CH}_{2}\right)_{\text {in }}$ protons. This is not seen.

Let us now focus on the only resonance $\alpha-\left(\mathrm{CH}_{2}\right)_{\text {in }}$ affected by the presence of ${ }^{113} \mathrm{Cd}$. Figure $7 \mathrm{~b}$ shows that very few $\chi^{2}$ regions (in yellow; for symmetry, only the range from 0 to $180^{\circ}$ needs to be considered), which determine the ${ }^{3} J\left({ }^{1} \mathrm{H}-\right.$ ${ }^{113} \mathrm{Cd}$ ) coupling constant values, provide average ${ }^{3} J\left({ }^{1} \mathrm{H}^{-113} \mathrm{Cd}\right)$ coupling constant values compatible with the experimentally determined $J$ value of $14.3 \mathrm{~Hz}$, at least within a prudential uncertainty of ca. $\pm 3 \mathrm{~Hz}: 0-13^{\circ}(J=16.5 \div 17.2 \mathrm{~Hz})$ and 128 $143^{\circ}(J=17.2 \div 11.3 \mathrm{~Hz})$. For steric reasons, however, the latter is the only plausible region. The reliability of this conclusion will be addressed for $\mathrm{Au}_{24} \mathrm{Cd}(\mathrm{SC} 2 \mathrm{Ph})_{18}{ }^{0}$.

$\mathrm{Au}_{24} \mathrm{Cd}(\mathrm{SC2Ph})_{18}{ }^{\mathbf{0}}$ and $\mathrm{Au}_{24} \mathbf{H g}(\mathbf{S C 2 P h})_{18}{ }^{0}$. The results and conclusions so far reached regard the butanethiolateprotected clusters and thus the question arises as to whether they are extendable to other ligands, also considering that the seminal works carried out by the groups of $\mathrm{Zhu}$ and $\mathrm{Wu}$ on $\mathrm{Cd}$ - and $\mathrm{Hg}$-doping focused on the phenylethanethiolate ligand. Indeed, since Donkers et al. described the first synthesis and isolation of $\mathrm{Au}_{25}$ protected by phenylethanethiolate ligands ${ }^{48}$ (Note: this cluster was originally believed to be $\left.\mathrm{Au}_{38}(\mathrm{SC} 2 \mathrm{Ph})_{24}\right)$, followed some years later by the actual crystallographic structure determination of $\left[\mathrm{Au}_{25}(\mathrm{SC} 2 \mathrm{Ph})_{18}{ }^{-}\right]\left(n-\mathrm{Oct}_{4} \mathrm{~N}\right)^{+},{ }^{29,30}$ phenylethanethiolate has been adopted by many research groups as sort of a reference ligand. We thus studied the $\mathrm{Cd}$ - and $\mathrm{Hg}$-doping of $\left[\mathrm{Au}_{25}(\mathrm{SC} 2 \mathrm{Ph})_{18}{ }^{-}\right]\left(n-\mathrm{Oct}_{4} \mathrm{~N}\right)^{+}$according to the same sequence of reactions and tests already described for the $\mathrm{SC} 4$ ligand.

$\mathrm{Au}_{24} \mathrm{Cd}(\mathrm{SC} 2 \mathrm{Ph})_{18}{ }^{0}$ was prepared according to the $\mathrm{Cd}(\mathrm{SC} 2 \mathrm{Ph})_{2},{ }^{20} \mathrm{Cd}\left(\mathrm{NO}_{3}\right)_{2},{ }^{21}$ and the $\mathrm{CdCl}_{2}$ (or ${ }^{113} \mathrm{CdCl}_{2}$ ) thiolate methods. As for the SC4 ligand, the corresponding MALDI-TOF (Figure S14) and UV-vis absorption spectroscopy spectra (Figure S1) show no differences. The ${ }^{1} \mathrm{H}$ NMR spectra of the $\mathrm{Au}_{24} \mathrm{Cd}(\mathrm{SC} 2 \mathrm{Ph})_{18}{ }^{0}$ sample obtained from $\mathrm{Cd}(\mathrm{SC} 2 \mathrm{Ph})_{2}$ (blue) and $\mathrm{Au}_{24}{ }^{113} \mathrm{Cd}(\mathrm{SC} 2 \mathrm{Ph})_{18}$ (red) are shown in Figure 8. The perfect overlap of the spectra in Figure 8 (but for the feature magnified in the inset, as discussed below) and Figure S16, which pertain to the three samples, confirms that preparing this doped cluster with the thiolate,${ }^{20}$ the salt, ${ }^{21}$ or the $\mathrm{CdCl}_{2}$ - thiolate method produces the very same result. A previously reported spectrum $\left(\mathrm{CD}_{2} \mathrm{Cl}_{2}, \mathrm{Cd}(\mathrm{SR})_{2}\right.$ synthesis $)$ shows similar features (Figure S7 in reference 20), whereas no NMR data were provided in the other report on Cd doping. ${ }^{21}$

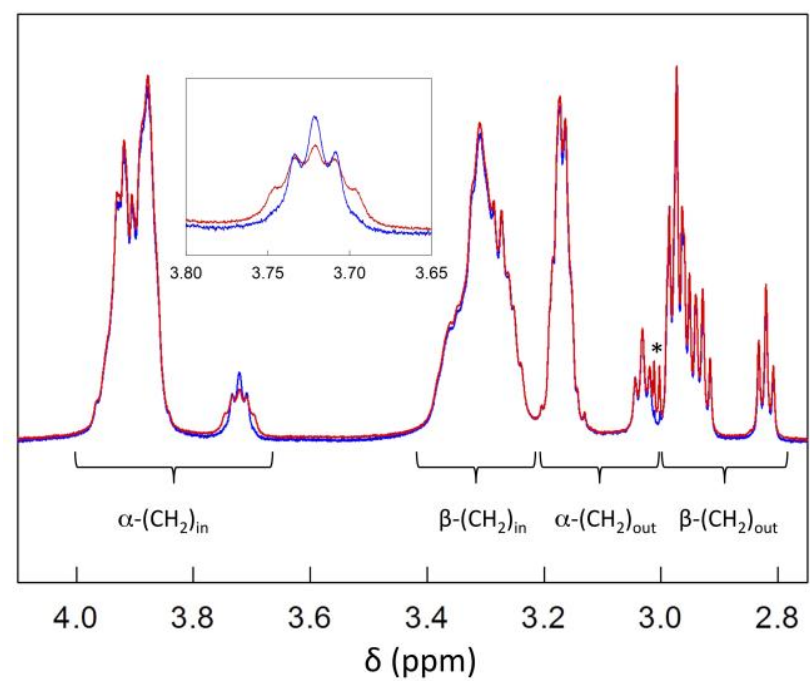

Figure 8. Full overlap of the ${ }^{1} \mathrm{H}$ NMR spectra of $2.2 \mathrm{mM}$ $\mathrm{Au}_{24} \mathrm{Cd}(\mathrm{SC} 2 \mathrm{Ph}){ }_{18}{ }^{0}$ (blue) and $2.2 \mathrm{mM} \mathrm{Au} 24^{113} \mathrm{Cd}(\mathrm{SC} 2 \mathrm{Ph})_{18}{ }^{0}$ (red) in $\mathrm{C}_{6} \mathrm{D}_{6}$ at $25{ }^{\circ} \mathrm{C}$ (region of the aliphatic $\mathrm{C}-\mathrm{H}$ signals). The inset highlights the effect of isotopic enrichment on the isolated $\alpha$ $\left(\mathrm{CH}_{2}\right)_{\text {in }}$ resonance. The star marks a solvent impurity (methanol).

The spectrum shows that the ligand symmetry is disrupted, which, once again, is inconsistent with $\mathrm{Cd}(\mathrm{c})$ doping. ${ }^{20}$ The COSY spectrum (Figure S15) allows attributing (Table S4) the complex signal at 4.0-3.8 ppm (integral corresponding to 11 ligands) to $22 \alpha-\left(\mathrm{CH}_{2}\right)_{\text {in }}$ protons, the slightly distorted triplet at $3.722 \mathrm{ppm}$ to the twelfth $\alpha-\left(\mathrm{CH}_{2}\right)$ in ligand, and the multiplet at 3.43-3.21 ppm to the $24 \beta-\left(\mathrm{CH}_{2}\right)_{\text {in }}$ protons. The $\alpha-$ $\left(\mathrm{CH}_{2}\right)_{\text {in }}$ signal at $3.722 \mathrm{ppm}$ correlates with the $\beta-\left(\mathrm{CH}_{2}\right)_{\text {in }}$ triplet at $3.287 \mathrm{ppm}$. The resonances corresponding to the 6 outer ligands appear as a complex multiplet of $\alpha-\left(\mathrm{CH}_{2}\right)_{\text {out }}$ resonances centered at 3.17 (10 protons) followed by one additional triplet at $3.031 \mathrm{ppm}$ ( 2 protons), and a series of largely overlapped $\beta-\left(\mathrm{CH}_{2}\right)_{\text {out }}$ triplets at $3.0-2.9 \mathrm{ppm}(10$ protons, five ligands) followed by one additional triplet (2 protons) at $2.820 \mathrm{ppm}$. The $\alpha-\left(\mathrm{CH}_{2}\right)_{\text {out }}$ and $\beta-\left(\mathrm{CH}_{2}\right)_{\text {out }}$ triplets at 3.031 and $2.820 \mathrm{ppm}$ correlate and thus belong to the same ligand. Careful analysis of the COSY spectrum, which was acquired during a particularly long time frame, allows distinguishing 12 nonisochronous inner ligands and 6 outer 
ligands (Table S4), which confirms on a quantitative basis the profound effect of Cd-doping on the ligand symmetry. Regarding the ${ }^{13} \mathrm{C}$ resonances, the values are pretty much isochronous (for the same position and ligand type), but for small differences for the isolated inner and outer signals.

The observation of an isolated triplet for both the inner and outer ligands is compatible with both $\mathrm{Cd}(\mathrm{i})$ and, intuitively, even more for $\mathrm{Cd}(\mathrm{s})$, as in this case both the $\alpha-\left(\mathrm{CH}_{2}\right)_{\text {out }}$ and $\beta$ $\left(\mathrm{CH}_{2}\right)_{\text {out }}$ resonances are significantly affected. Can this be taken as the proof that the staple position is preferable? To clarify the position of the $\mathrm{Cd}$ atom, we followed the same procedure used for SC4. First, we checked that the reaction with $\mathrm{CdCl}_{2}$ proceeds smoothly and then used ${ }^{113} \mathrm{CdCl}_{2}$ to prepare $\mathrm{Au}_{24}{ }^{113} \mathrm{Cd}(\mathrm{SC} 2 \mathrm{Ph})_{18}{ }^{0}$. Figure 8 shows that only the isolated $\alpha-\left(\mathrm{CH}_{2}\right)_{\text {in }}$ is affected by ${ }^{113} \mathrm{Cd}$, while the rest of the ${ }^{1} \mathrm{H}$ NMR spectrum is perfectly superimposable to that of $\mathrm{Au}_{24} \mathrm{Cd}(\mathrm{SC} 2 \mathrm{Ph})_{18}{ }^{0}$. The inset of Figure 8 shows the detail of this effect. Decoupling was carried out for both $\mathrm{Au}_{24}{ }^{113} \mathrm{Cd}(\mathrm{SC} 2 \mathrm{Ph})_{18}{ }^{0}$ and $\mathrm{Au}_{24} \mathrm{Cd}(\mathrm{SC} 2 \mathrm{Ph})_{18}{ }^{0}$, and the effects on both $\alpha-\left(\mathrm{CH}_{2}\right)_{\text {in }}$ and $\alpha-\left(\mathrm{CH}_{2}\right)_{\text {out }}$ were tested. As expected on the basis of the ${ }^{1} \mathrm{H}$ NMR spectra, the only effect is on the isolated $\alpha-\left(\mathrm{CH}_{2}\right)_{\text {in }}$ resonance (Figure S17). Not only the effect is qualitatively the same as described for SC4, but also the ${ }^{3} \mathrm{~J}\left({ }^{1} \mathrm{H}_{-}{ }^{113} \mathrm{Cd}\right)$ coupling constant is quite similar, $13.6(0.2) \mathrm{Hz}$. As observed for $\mathrm{Au}_{24} \mathrm{Cd}(\mathrm{SC} 4)_{18}{ }^{0}$ (Figure 6), a trace of the $\alpha$ $\left(\mathrm{CH}_{2}\right)_{\text {in }}$ doublet obtained upon decoupling could be detected also in the $\mathrm{Au}_{24} \mathrm{Cd}(\mathrm{SC} 2 \mathrm{Ph})_{18}{ }^{0}$ sample. These results confirm that the $\mathrm{Cd}$ dopant is on the icosahedron, as demonstrated above for the $\mathrm{C} 4$ cluster and originally suggested by $\mathrm{Wu}$ and co-workers for the $\mathrm{C} 2 \mathrm{Ph}$ cluster. ${ }^{21}$

According to the correlation between the ${ }^{3} J\left({ }^{1} \mathrm{H}-{ }^{113} \mathrm{Cd}\right)$ coupling constant and the $\mathrm{H}-\mathrm{C}-\mathrm{S}-\mathrm{Cd}$ dihedral angle, ${ }^{43,44}$ the virtually identical coupling constants determined experimentally for the $\mathrm{SC} 4$ and $\mathrm{SC} 2 \mathrm{Ph}$ ligands point to very similar H-C-S-Cd dihedral angles. As described later, we could obtain the structures of both $\mathrm{Au}_{24} \mathrm{Cd}(\mathrm{SC} 4)_{18}{ }^{0}$ and $\mathrm{Au}_{24} \mathrm{Cd}(\mathrm{SC} 2 \mathrm{Ph})_{18}{ }^{0}$ by single-crystal $\mathrm{X}$-ray crystallography. Whereas the former is affected by intercluster interactions, the latter refers to unbounded clusters. $\mathrm{Au}_{24} \mathrm{Cd}(\mathrm{SC} 2 \mathrm{Ph})_{18}{ }^{0}$ thus provides an ideal case to test on quantitative grounds the validity of the ${ }^{3} \mathrm{~J}\left({ }^{1} \mathrm{H}_{-}{ }^{113} \mathrm{Cd}\right)$ coupling constant correlation, which was originally described for metalloproteins, also for gold nanoclusters. According to the correlation, the experimentally determined $J$ value corresponds (within ca. 3 $\mathrm{Hz})$ to plausible angle $\chi^{2}$ values of $130 \div 145^{\circ}(J=16.6 \div$ $10.6 \mathrm{~Hz})$. In the structure of $\mathrm{Au}_{24} \mathrm{Cd}(\mathrm{SC} 2 \mathrm{Ph})_{18}{ }^{0}$, we find that the average $C^{\beta}-C^{\alpha}-S-C d$ dihedral angle $\chi^{2}$ is $149^{\circ}$; similar values can be obtained from the structures published by Wang et al., $150^{\circ},{ }^{20}$ and Yao et al., $133^{\circ} .{ }^{21}$ These figures yield an average $\chi^{2}$ of $144^{\circ}$, which is indeed in excellent agreement with the estimated range, also considering the usual limits of comparing solid- to solution-phase results.

$\mathrm{Au}_{24} \mathrm{Hg}(\mathrm{SC} 2 \mathrm{Ph})_{18}{ }^{0}$ was also prepared in three ways: (i) metal exchange on $\mathrm{Au}_{25}(\mathrm{SC} 2 \mathrm{Ph})_{18}{ }^{-}$with $\mathrm{Hg}(\mathrm{SC} 2 \mathrm{Ph})_{2}{ }^{20}$ and $\mathrm{Hg}\left(\mathrm{NO}_{3}\right)_{2},{ }^{23}$ and metal exchange on preformed $\mathrm{Au}_{24} \mathrm{Cd}(\mathrm{SC} 2 \mathrm{Ph})_{18}{ }^{0}$ with $\mathrm{Hg}\left(\mathrm{NO}_{3}\right)_{2} .{ }^{21}$ After purification and recrystallization, the three $\mathrm{Au}_{24} \mathrm{Hg}(\mathrm{SC} 2 \mathrm{Ph})_{18}$ samples were characterized by UV-vis absorption spectroscopy (Figure S1), electrochemistry (see next section), and MALDI-TOF mass spectrometry, which gave the same fragmentation pattern (Figure S18).
The three $\mathrm{Au}_{24} \mathrm{Hg}(\mathrm{SC} 2 \mathrm{Ph})_{18}{ }^{0}$ samples exhibit identical ${ }^{1} \mathrm{H}$ NMR spectra, even from the viewpoint of minor features (Figure S19 allows appreciating the perfect correspondence of the three spectra). The typical ${ }^{1} \mathrm{H}$ NMR pattern of $\mathrm{Au}_{24} \mathrm{Hg}(\mathrm{SC} 2 \mathrm{Ph})_{18}{ }^{0}$ is exemplified in Figure 9a, which pertains to the sample obtained upon metal exchange on a preformed $\mathrm{Au}_{24} \mathrm{Cd}(\mathrm{SC} 2 \mathrm{Ph})_{18}{ }^{0}$ cluster. Please note that whereas the $\mathrm{Hg}\left(\mathrm{NO}_{3}\right)_{2}$ synthesis is supposed to yield $\mathrm{Hg}(\mathrm{s}),{ }^{23}$ for the double exchange we purposely used $\mathrm{Au}_{24} \mathrm{Cd}(\mathrm{SC} 2 \mathrm{Ph})_{18}{ }^{0}$ obtained using $\mathrm{Cd}(\mathrm{SR})_{2}$, as this sample is that supposed to produce $\mathrm{Cd}(\mathrm{c}) .^{20}$

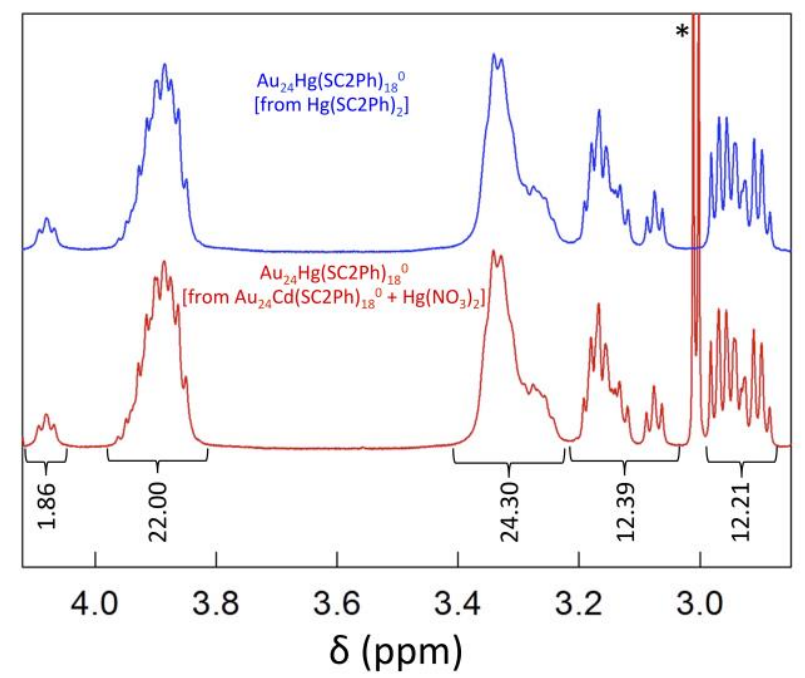

Figure 9. ${ }^{1} \mathrm{H} \mathrm{NMR}$ spectrum of $2.2 \mathrm{mM} \mathrm{Au}_{24} \mathrm{Hg}(\mathrm{SC} 2 \mathrm{Ph})_{18}{ }^{0}$ (aliphatic C-H signals) obtained from $\mathrm{Hg}(\mathrm{SC} 2 \mathrm{Ph})_{2}$ (blue trace) or after exchange on a preformed $\mathrm{Au}_{24} \mathrm{Cd}(\mathrm{SC} 2 \mathrm{Ph})_{18}{ }^{0}$ cluster (red trace). The integrals and ligand types are indicated. The asterisk marks a solvent impurity (methanol).

The ${ }^{1} \mathrm{H}$ NMR spectrum exhibits four groups of peaks. Assignments were carried out through COSY measurements (Figure S20), and the corresponding ${ }^{1} \mathrm{H}$ and ${ }^{13} \mathrm{C}$ chemical shifts are provided in Table S5. As for $\mathrm{Au}_{24} \mathrm{Cd}(\mathrm{SC} 2 \mathrm{Ph})_{18}{ }^{0}$, the inner resonances $\alpha-\left(\mathrm{CH}_{2}\right)_{\text {in }}$ and $\beta-\left(\mathrm{CH}_{2}\right)_{\text {in }}$ are clearly separated from the two outer resonances $\alpha-\left(\mathrm{CH}_{2}\right)_{\text {out }}$ and $\beta-\left(\mathrm{CH}_{2}\right)_{\text {out }}$. For both $\alpha-\left(\mathrm{CH}_{2}\right)_{\text {in }}$ and $\alpha-\left(\mathrm{CH}_{2}\right)_{\text {out }}$, one of the triplets is well separated from the others. As for SC4, the isolated $\alpha-\left(\mathrm{CH}_{2}\right)_{\text {in }}$ signal is downfield with respect to the group of the remaining 11 ligands, whereas it is upfield for the outer ligands. The COSY analysis of the $\alpha-\left(\mathrm{CH}_{2}\right)_{\text {in }}$ and $\alpha-\left(\mathrm{CH}_{2}\right)_{\text {out }}$ resonances allowed estimating the presence of each of the 12 and 6 ligands, respectively. Nonisochronous signals are also detected for the corresponding $\beta-\left(\mathrm{CH}_{2}\right)_{\text {in }}$ and $\beta-\left(\mathrm{CH}_{2}\right)_{\text {out }}$ resonances. As to ${ }^{13} \mathrm{C}$, the signals are isochronous, with a few exceptions. Once again, the number of clearly distinguishable resonances and isochronous signals witnesses the significant loss of symmetry undergone upon $\mathrm{Hg}$-doping. It is worth noticing that the ${ }^{1} \mathrm{H}$ NMR spectra obtained for $\mathrm{Au}_{24} \mathrm{Hg}(\mathrm{SC} 2 \mathrm{Ph})_{18}{ }^{0}$ (Figure S16 in reference 24 and Figure S7 in reference 20) show very similar features (our data were obtained in $\mathrm{C}_{6} \mathrm{D}_{6}$, whereas those published data pertain to $\mathrm{CD}_{2} \mathrm{Cl}_{2}$ ), though they were not specifically discussed. Overall, the NMR analysis shows that the $\mathrm{Hg}$ atom cannot be at the central position of the cluster, as previously hypothesized. ${ }^{20}$ 
As to its actual position, we argued that the fast $\mathrm{Hg}$ exchange on a preformed $\mathrm{Au}_{24} \mathrm{Cd}(\mathrm{SC} 2 \mathrm{Ph})_{18}{ }^{0}$ cluster occurs on the icosahedron as well, i.e., directly on the site occupied by $\mathrm{Cd}(\mathrm{i})$, rather than involving a complicate molecular rearrangements where first $\mathrm{Hg}$ exchanges $\mathrm{Cd}(\mathrm{i})$ and then switches position with the nearby $\mathrm{Au}(\mathrm{s})$ atom. To gain insights into this problem, we applied the same decoupling sequence used for the Cd-doped clusters. The goal was to detect a possible ${ }^{3} J\left({ }^{1} \mathrm{H}-{ }^{199} \mathrm{Hg}\right)$ coupling by relying on the fact that ${ }^{199} \mathrm{Hg}$ has a natural abundance of $16.94 \%$ and is a spin $1 / 2$ isotope. Assuming that a Karplus-type correlation is valid also for the three-bond system $\mathrm{H}-\mathrm{C}-\mathrm{S}-\mathrm{Hg}$, one would expect to see some ${ }^{3} J\left({ }^{1} \mathrm{H}-{ }^{199} \mathrm{Hg}\right)$ coupling only for $\alpha-\left(\mathrm{CH}_{2}\right)$ in or both $\alpha$ $\left(\mathrm{CH}_{2}\right)_{\text {in }}$ and $\alpha-\left(\mathrm{CH}_{2}\right)_{\text {out }}$ for $\mathrm{Hg}(\mathrm{i})$ and $\mathrm{Hg}(\mathrm{s})$, respectively. Radiating the corresponding $\beta-\left(\mathrm{CH}_{2}\right)_{\text {in }}$ signal (assessed via TOCSY) transforms the $\alpha-\left(\mathrm{CH}_{2}\right)_{\text {in }}$ signal into a singlet accompanied by a doublet (Figure S21a) that allows calculating a ${ }^{3} J\left({ }^{1} \mathrm{H}^{-199} \mathrm{Hg}\right)$ coupling constant of $36 \mathrm{~Hz}$. Conversely, radiating the $\beta-\left(\mathrm{CH}_{2}\right)_{\text {out }}$ signal transforms the corresponding isolated $\alpha-\left(\mathrm{CH}_{2}\right)_{\text {out }}$ signal into an uncomplicated singlet (Figure S21b). We also applied the same decoupling analysis to the isolated $\alpha-\left(\mathrm{CH}_{2}\right)_{\text {in }}$ signal of $\mathrm{Au}_{24} \mathrm{Hg}(\mathrm{SC} 4)_{18}{ }^{0}$, obtained the same outcome, and calculated the very similar value of $37 \mathrm{~Hz}$ (Figure 10), whereas no effect was detected for the isolated $\alpha-\left(\mathrm{CH}_{2}\right)_{\text {out }}$ resonance. Although to the best of our knowledge a Karplus-like dependence has never been observed for ${ }^{199} \mathrm{Hg}$, it is conceivable that a periodic dependence such as that found for ${ }^{3} J\left({ }^{1} \mathrm{H}^{-113} \mathrm{Cd}\right)^{44,45}$ should be qualitatively valid also for of the ${ }^{3} J\left({ }^{1} \mathrm{H}^{-199} \mathrm{Hg}\right)$ coupling. The virtually identical values determined for $\mathrm{C} 2 \mathrm{Ph}$ and $\mathrm{C} 4$ would thus point to very similar average dihedral angles, as determined for the Cd-doped clusters. Most important, these results provide compelling evidence that $\mathrm{Hg}$-doping, whether performed directly on $\mathrm{Au}_{25}(\mathrm{SR})_{18}{ }^{-}$or indirectly on $\mathrm{Au}_{24} \mathrm{Cd}(\mathrm{SR})_{18}{ }^{0}$, consistently yields $\mathrm{Hg}(\mathrm{i})$, rather than $\mathrm{Hg}(\mathrm{s}) .{ }^{23}$

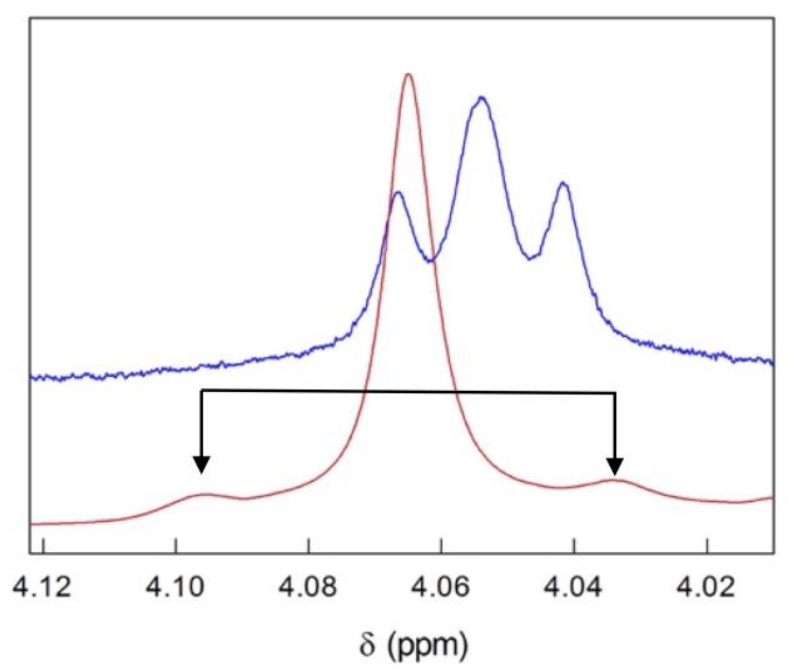

Figure 10. ${ }^{1} \mathrm{H}$ NMR spectra of $2.1 \mathrm{mM} \mathrm{Au}_{24} \mathrm{Hg}(\mathrm{SC} 4)_{18}{ }^{0}$, focusing on the isolated $\alpha-\left(\mathrm{CH}_{2}\right)$ in region before (blue) and after (red) ${ }^{1} \mathrm{H}-{ }^{1} \mathrm{H}$ homodecoupling at the frequency of the corresponding $\beta-\left(\mathrm{CH}_{2}\right)_{\text {in }}$ signal. The two spectra are vertically shifted for clarity and the arrows mark the doublet. $\mathrm{C}_{6} \mathrm{D}_{6}, 25^{\circ} \mathrm{C}$.

To conclude, NMR demonstrates that both $\mathrm{Cd}$ and $\mathrm{Hg}$ are exchanged on the icosahedron, no matter the synthetic method employed or the nature of the ligand. It should be also noted that the MALDI-TOF mass spectra of the samples obtained for each doped clusters are identical (Figures S6, S12, S14, and $\mathrm{S} 18$ ). As either foreign-metal atom is on the icosahedron, differences in the fragmentation patterns observed between the $\mathrm{Hg}$ and $\mathrm{Cd}$ doped clusters should not to be taken as indicating a different doping position. ${ }^{23}$ Rather, they just reflect the effect of the specific doping element, as also supported by the similar fragmentation patterns exhibited for the same doping metal by the $\mathrm{SC} 4$ and $\mathrm{SC} 2 \mathrm{Ph}$ protected clusters.

Electrochemistry of $\mathbf{A u}_{24} \mathbf{M}(\mathbf{S R})_{18}$. The electrochemical measurements were carried out in dichloromethane (DCM) containing $0.1 \mathrm{M}$ tetrabutylammonium hexafluorophosphate (TBAH), using a glassy carbon (GC) microdisk electrode. Figure 11a compares the DPV behavior of $\mathrm{Au}_{24} \mathrm{M}(\mathrm{SC} 4)_{18}$ for $\mathrm{M}=\mathrm{Au}, \mathrm{Pt}, \mathrm{Cd}$, and $\mathrm{Hg}$. Figure $11 \mathrm{~b}$ shows the DPV behavior of the $\mathrm{Au}_{24} \mathrm{M}(\mathrm{SC} 2 \mathrm{Ph})_{18}$ samples $(\mathrm{M}=\mathrm{Au}, \mathrm{Cd}, \mathrm{Hg})$. As expected, for both the $\mathrm{Hg}$ - and $\mathrm{Cd}$-doped clusters the various samples exhibit exactly the same DPV pattern and formal potential $\left(E^{\circ}\right)$ values. This is exemplified for both ligands in Figure S22, which shows the DPVs of the $\mathrm{Hg}$ samples obtained with the $\mathrm{Hg}\left(\mathrm{NO}_{3}\right)_{2}$, thiolate, and $\mathrm{Cd}$ exchange methods.

The DPVs of $\mathrm{Au}_{24} \mathrm{Hg}(\mathrm{SC} 4)_{18}{ }^{0}$ and $\mathrm{Au}_{24} \mathrm{Cd}(\mathrm{SC} 4)_{18}{ }^{0}$ are qualitatively similar to that of $\mathrm{Au}_{25}(\mathrm{SC} 4)_{18}{ }^{-}$. The doped clusters undergo two successive one-electron oxidations $\left(E^{\circ}{ }_{1}\right.$ and $\left.E^{\circ}{ }_{2}\right)$ at 0.364 and $0.684 \mathrm{~V}, \mathrm{Au}_{24} \mathrm{Hg}(\mathrm{SC} 4)_{18}{ }^{0}$, and 0.332 and $0.636 \mathrm{~V}, \mathrm{Au}_{24} \mathrm{Cd}(\mathrm{SC} 4)_{18}{ }^{0}$. In the timescale of voltammetry experiments, both processes are reversible. Further oxidation processes are detectable at more positive potentials, though with formation of chemically labile species. The $E^{\circ}$ for the first peak of these doped clusters is more positive than that of $\mathrm{Au}_{25}(\mathrm{SC} 4)_{18}{ }^{-}\left(E^{\circ}{ }_{1}=-0.188, E^{\circ}{ }_{2}=0.139 \mathrm{~V}\right.$, respectively ${ }^{49}$ by 0.552 and $0.520 \mathrm{~V}$, respectively. For $\mathrm{Au}_{24} \mathrm{Hg}(\mathrm{SC} 2 \mathrm{Ph})_{18}{ }^{0}\left(E^{\circ}{ }_{1}^{\circ}=\right.$ $\left.0.451, E_{2}^{\circ}=0.703 \mathrm{~V}\right)$ and $\mathrm{Au}_{24} \mathrm{Cd}(\mathrm{SC} 2 \mathrm{Ph})_{18}{ }^{\circ}\left(E^{\circ}{ }_{1}=0.430, E^{\circ}{ }_{2}\right.$ $=0.668 \mathrm{~V})$ similar considerations apply. With respect to $\mathrm{Au}_{24}(\mathrm{SC} 2 \mathrm{Ph}){ }_{18}{ }^{-}\left(E^{\circ}{ }_{1}=-0.077, E^{\circ}{ }_{2}=0.226 \mathrm{~V}\right),{ }^{50}$ the positive shifts of $E^{\circ}{ }_{1}$ are 0.528 and $0.507 \mathrm{~V}$, respectively. For both $\mathrm{Hg}$ and $\mathrm{Cd}$, this remarkable positive shift was already observed. ${ }^{23,51}$

Regarding the first reduction peak, which for $\mathrm{Au}_{24} \mathrm{Hg}(\mathrm{SC} 4)_{18}{ }^{0}$ and $\mathrm{Au}_{24} \mathrm{Cd}(\mathrm{SC} 4)_{18}{ }^{0}$ occurs at -1.23 and $-1.39 \mathrm{~V}$, respectively, the formation of the anion is chemically irreversible. For the latter, increasing the $\mathrm{CV}$ potential scan rate $(v)$ allows to detect reversibility, and therefore, determine an $E^{\circ}$ value of $-1.38 \mathrm{~V}$. We described this procedure in detail for a series of $\mathrm{Au}_{25}(\mathrm{SR})_{18}$ clusters. ${ }^{50,52,53}$ The electrochemical gap of $\mathrm{Au}_{24} \mathrm{Cd}(\mathrm{SC} 4)_{18}{ }^{0}$ can thus be calculated from the $E^{\circ}$ difference between the $+1 / 0$ and $0 /-1$ redox couples. The corresponding HOMO-LUMO gap can then be estimated by subtracting the charging-energy contribution, obtained from the $E^{\circ}$ difference between the $+2 /+1$ and $+1 / 0$ states. ${ }^{54}$ The value so-obtained, $1.41 \mathrm{eV}$, is in very good agreement with the HOMO-LUMO gap of $1.37 \mathrm{eV}$ estimated from the onset of optical absorption (Figure 2). For $\mathrm{Au}_{24} \mathrm{Cd}(\mathrm{SC} 2 \mathrm{Ph})_{18}{ }^{0}$ we observed the same behavior, and this allows calculating an $E^{\circ}$ value of $-1.26 \mathrm{~V}$ for the $0 /-1$ redox couple. The HOMOLUMO gap is thus estimated to be $1.46 \mathrm{eV}$, to be compared with that obtained from the optical spectrum (Figure S1), 1.41 $\mathrm{eV}$ and the value of 1.4(0.1) eV obtained by time-resolved spectroscopic analysis. ${ }^{22}$

For both SC4 and SC2Ph ligands, the analysis of the reduction of the $\mathrm{Hg}$-doped clusters is more complicated 
because the voltammetric peak exhibits features that suggest interaction with the electrode surface. Furthermore, for both $\mathrm{Hg}$-doped clusters the peak is irreversible also at high $v$ values (up to $\left.50 \mathrm{~V} \mathrm{~s}^{-1}\right)$. However, at low temperature $\left(-45^{\circ} \mathrm{C}\right.$ ) and high $v$ some reversibility is detectable, which allows estimating $E^{\circ}$. By comparing this result with the corresponding $E^{\circ}$ determined at the same temperature for $\mathrm{Au}_{25}(\mathrm{SC} 2 \mathrm{Ph})_{18}{ }^{-}$, the $E^{\circ}$ values of the two $\mathrm{Au}_{24} \mathrm{Hg}(\mathrm{SR})_{18}{ }^{0}$ clusters at $25{ }^{\circ} \mathrm{C}$ could be estimated. Calculation of the HOMO-LUMO gap yields 1.28 (SC4) and 1.29 (SC2Ph),
Figure 11. Comparison between the DPV curves for (top to bottom): (a) $\mathrm{Au}_{25}(\mathrm{SC} 4)_{18}{ }^{-}, \mathrm{Au}_{24} \mathrm{Pt}(\mathrm{SC} 4)_{18}{ }^{0}, \mathrm{Au}_{24} \mathrm{Cd}(\mathrm{SC} 4)_{18}{ }^{0}$, and $\mathrm{Au}_{24} \mathrm{Hg}(\mathrm{SC} 4)_{18}{ }^{0}$; (b) $\mathrm{Au}_{25}(\mathrm{SC} 2 \mathrm{Ph})_{18}{ }^{-}, \mathrm{Au}_{24} \mathrm{Cd}(\mathrm{SC} 2 \mathrm{Ph})_{18}{ }^{0}$, and $\mathrm{Au}_{24} \mathrm{Hg}(\mathrm{SC} 2 \mathrm{Ph})_{18}{ }^{0}$. Glassy-carbon electrode, DCM/0.1 M TBAH, $25^{\circ} \mathrm{C}$. respectively; these gaps are thus slightly smaller than those electrochemically determined for $\mathrm{Au}_{25}(\mathrm{SC} 4)_{18}{ }^{-}$and $\mathrm{Au}_{25}(\mathrm{SC} 2 \mathrm{Ph})_{18}{ }^{-}, \quad 1.30$ and $1.34 \mathrm{eV}$, respectively. ${ }^{49,55} \mathrm{~A}$ very recent time-resolved spectroscopy analysis led for $\mathrm{Au}_{24} \mathrm{Hg}(\mathrm{SC} 2 \mathrm{Ph})_{18}{ }^{0}$ and $\mathrm{Au}_{25}(\mathrm{SC} 2 \mathrm{Ph})_{18}{ }^{-}$to the similar values of $1.2(0.1)$ and $1.3(0.1) \mathrm{eV}$, respectively. ${ }^{22}$ Very recent calculations provided a similar decrease in the HOMO-LUMO gap energy on going from $\mathrm{Cd}$ to $\mathrm{Hg}$, as well as valuable insights into the electronic effects introduced by dopants. ${ }^{36}$

The DPV of $\mathrm{Au}_{24} \mathrm{Pt}(\mathrm{SC} 4)_{18}{ }^{0}$ clearly points to a different orbital-energy distribution. It shows two pairs of peaks corresponding to the formation of the mono- and dication on the positive-going scan $\left(E^{\circ}\right.$ of 0.475 and $\left.0.853 \mathrm{~V}\right)$, and the mono- and dianion on the negative-going scan $\left(E^{\circ}\right.$ of -0.287 and $-0.622 \mathrm{~V}$ ). Each of these charge states is chemically stable. For this cluster, a HOMO-LUMO gap of $0.384 \mathrm{eV}$ can be estimated from the electrochemical data (for the charging energy correction, we used the potential difference calculated for the two oxidation peaks, $0.378 \mathrm{~V}$ ) is much lower than for the other clusters investigated. A previous electrochemical analysis carried out on $\mathrm{Au}_{24} \mathrm{Pt}(\mathrm{SC} 6)_{18}{ }^{0}$ yielded the similar value of $0.34 \mathrm{eV} .{ }^{14}$ With $\mathrm{SC} 4$, however, we fail to detect the large potential difference reported for the $E^{\circ}{ }_{1}$ of $\mathrm{Au}_{25}(\mathrm{SC} 6)_{18}$ and the first reduction peak of $\mathrm{Au}_{24} \mathrm{Pt}(\mathrm{SC} 6)_{18}{ }^{0}{ }^{14}$

Overall, some of our electrochemical data essentially confirm previous electrochemical conclusions on the position occupied by $\mathrm{Pt}$ upon $\mathrm{Au}_{25}$-doping ${ }^{14}$ and the effect of $\mathrm{Hg}$ doping. ${ }^{23}$ Most important, however, they provide further compelling evidence that $\mathrm{Hg}$ - and $\mathrm{Cd}$-doping always occur on the same metal site, no matter the ligand and how metal exchange is carried out.

Single Crystal X-Ray Crystallography. We could solve the structure of most of the clusters, sometimes also as the result of different syntheses and in two laboratories, as specified: $\mathrm{Au}_{24} \mathrm{Pt}(\mathrm{SC} 4)_{18}{ }^{0}$ (Padova), $\mathrm{Au}_{24} \mathrm{Hg}(\mathrm{SC} 4)_{18}{ }^{0}$ (from $\left.\mathrm{Hg}(\mathrm{SC} 4)_{2}, \quad J y v a ̈ s k y l a ̈\right), \quad \mathrm{Au}_{24} \mathrm{Cd}(\mathrm{SC} 4)_{18}{ }^{0}$ (from $\mathrm{Cd}\left(\mathrm{NO}_{3}\right)_{2}$, Jyväskylä), $\mathrm{Au}_{24} \mathrm{Cd}(\mathrm{SC} 4)_{18}{ }^{0}$ (from $\left.\mathrm{Cd}(\mathrm{SC} 4)_{2}, \quad J y v a ̈ s k y l a ̈\right)$, $\mathrm{Au}_{24} \mathrm{Hg}(\mathrm{SC} 2 \mathrm{Ph})_{18}{ }^{0}$ (from $\mathrm{Hg}\left(\mathrm{NO}_{3}\right)_{2}$, Padova and Jyväskylä), $\mathrm{Au}_{24} \mathrm{Hg}(\mathrm{SC} 2 \mathrm{Ph})_{18}{ }^{0}$ (from $\mathrm{Hg}\left(\mathrm{NO}_{3}\right)_{2}+\mathrm{Au}_{24} \mathrm{Cd}(\mathrm{SC} 2 \mathrm{Ph})_{18}{ }^{0}$, Padova and Jyväskylä), and $\mathrm{Au}_{24} \mathrm{Cd}(\mathrm{SC} 2 \mathrm{Ph})_{18}{ }^{0}$ (from $\mathrm{Cd}(\mathrm{SC} 4)_{2}$, Jyväskylä). Here we will focus on the most salient aspects, whereas full discussion on these results is provided in the Supporting Information.

For both $\mathrm{Au}_{24} \mathrm{Hg}(\mathrm{SC} 4)_{18}{ }^{0}$ and $\mathrm{Au}_{24} \mathrm{Cd}(\mathrm{SC} 4)_{18}{ }^{0}$, the structure shows the very same features discovered for $\mathrm{Au}_{25}(\mathrm{SC} 4)_{18}{ }^{0}$ (this cluster is a neutral radical) ${ }^{37}$ and $\mathrm{Au}_{25}(\mathrm{SC} 5)_{18}{ }_{18}:^{39}$ (i) the clusters form linear polymers of interconnected clusters; (ii) the connecting staples form S-Au-Au-S dihedral angles of nearly $90^{\circ}$ (for both $\mathrm{Hg}$ - and $\mathrm{Cd}$-doping, $81-85^{\circ}$ ); (iii) the neighboring clusters are connected via aurophilic $\mathrm{Au}-\mathrm{Au}$ bonds. Formation of the polymers is thus granted by a twistand-lock mechanism ${ }^{37}$ in which the orientation of the alkyl chains and their van der Waals interaction opens up two opposite sides of the Au-S-Au staples and favor a closer approach between neighboring clusters, thereby causing formation of an intercluster $\mathrm{Au}-\mathrm{Au}$ aurophilic bond. In the doped clusters, this bond has a similar length, $3.09 \AA$ ( $\mathrm{Hg}$ doping) and $3.10 \AA$ (Cd-doping), as found in $\mathrm{Au}_{25}(\mathrm{SC} 4)_{18}{ }^{0}$ $(3.15 \AA)^{37}$ and $\mathrm{Au}_{25}(\mathrm{SC} 5)_{18}{ }^{0}(2.98 \div 3.03 \AA) .{ }^{39}$ These results thus point to the importance of the alkanethiolate ligand, and show that formation of the intercluster aurophilic bond is possible regardless of the magnetic state of the cluster: in fact, 
as opposed to $\mathrm{Au}_{25}(\mathrm{SC} 4)_{18}{ }^{0}$, both the $\mathrm{Hg}$ - and $\mathrm{Cd}$-doped clusters are diamagnetic, as evinced from the NMR results and previously shown for $\mathrm{Au}_{24} \mathrm{Hg}(\mathrm{SC} 2 \mathrm{Ph})_{18}{ }^{0}$ by electron paramagnetic resonance. ${ }^{23}$

With that being said, we note that $\mathrm{Au}_{24} \mathrm{Pt}(\mathrm{SC} 4)_{18}{ }^{0}$, which was purposely prepared with the SC4 ligand, does not form polymers. Its structure does not show any rotation of the staples, which remains virtually parallel, and shows a relatively large minimum intercluster $\mathrm{Au}-\mathrm{Au}$ distance of 3.88 $\AA$. This is as previously observed for, say, $\mathrm{Au}_{25}(\mathrm{SC} 2)_{18}{ }^{0}$, which shows a minimum intercluster $\mathrm{Au}-\mathrm{Au}$ distance of 4.12 $\AA{ }^{54}$ and $\mathrm{Au}_{25}(\mathrm{SC} 3)_{18}{ }^{0}{ }^{38}$ Overall, this may suggest that electronic factors may also play a role in determining the different behavior observed for $\mathrm{Au}_{24} \mathrm{Pt}(\mathrm{SC} 4)_{18}{ }^{0}$.

Crystallographic analysis alone is not distinctive enough for determining the positions of these doping metals with reliable accuracy. This is due to the very small electron-density differences between $\mathrm{Au}$ and the $\mathrm{Pt}, \mathrm{Hg}$, and $\mathrm{Cd}$ metals, especially for $\mathrm{Pt}$ and $\mathrm{Hg}$ that differ from $\mathrm{Au}$ by only one electron. Thus, an $\mathrm{Au}$ site substituted by $\mathrm{Hg}$ or Pt should show an electron density higher or lower than that of Au by only $1.2 \%$, respectively. This figure will be significantly lowered if the doping metal is disordered over two or more locations ( $\sim 0.1 \%$ difference when all 12 icosahedral sites are partially but evenly occupied; even less if distribution also involves the staples) and/or if the quality of the crystal is less than ideal. This implies that for these clusters small differences in electron densities cannot be determined reliably even with the highest quality data obtained by the modern in house diffractometers. However, thorough analysis of the structure of the $\mathrm{Cd}$ doped clusters (the electron-density difference between $\mathrm{Cd}$ and $\mathrm{Au}$ is $~ 60 \%$ ) using several data sets with the highest possible data quality (data redundancy of 5) allowed us to refine the structure of the Cd-doped cluster quite satisfactorily. Consistently with the NMR analysis, refinement indicated that $\mathrm{Cd}$ is most likely disorderly located on the icosahedral sites instead of the center or staples. For the $\mathrm{Hg}$ and $\mathrm{Pt}$ doped $\mathrm{Au}_{24} \mathrm{M}(\mathrm{SC} 4)_{18}{ }^{0}$ clusters, on the other hand, the electron-density difference is just too small to draw similar conclusions.

Regarding the $\mathrm{SC} 2 \mathrm{Ph}$-protected clusters, $\mathrm{Au}_{24} \mathrm{Hg}(\mathrm{SC} 2 \mathrm{Ph})_{18}{ }^{0}$ and $\mathrm{Au}_{24} \mathrm{Cd}(\mathrm{SC} 2 \mathrm{Ph})_{18}{ }^{0}$ show exactly the same structure, where the orientation of the ligands with respect to plane of the staple is always of the up-down-up type (Figure 12). This is, therefore, identical to the ligand orientation seen in $\mathrm{Au}_{25}(\mathrm{SC} 2 \mathrm{Ph})_{18}{ }^{0},{ }^{39}$ though different from that observed in $\mathrm{Au}_{25}(\mathrm{SC} 2 \mathrm{Ph})_{18}{ }^{-}$, which is always of the up-down-down type. ${ }^{31,32}$ Finally, we checked the two structures of $\mathrm{Au}_{24} \mathrm{Hg}(\mathrm{SC} 2 \mathrm{Ph})_{18}{ }^{0}$ obtained upon metal exchange in either $\mathrm{Au}_{25}(\mathrm{SC} 2 \mathrm{Ph})_{18}{ }^{-}$or $\mathrm{Au}_{24} \mathrm{Cd}(\mathrm{SC} 2 \mathrm{Ph})_{18}{ }^{0}$, and found they are identical. Further discussion on the SC4- and SC2Ph-protected clusters is provided in the Supporting Information.

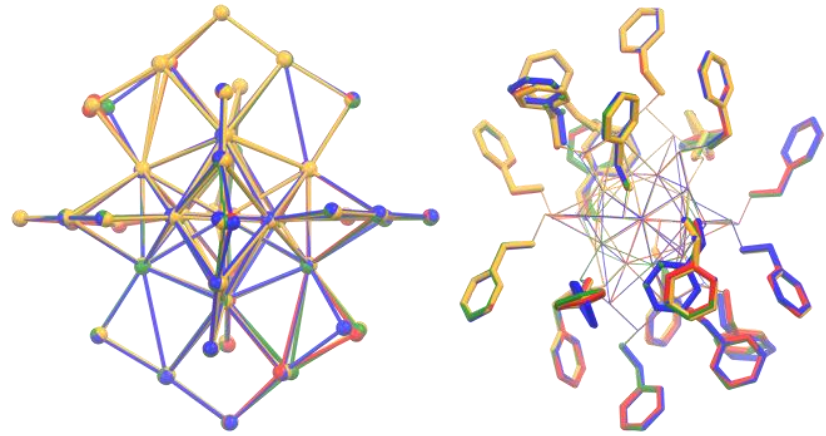

Figure 12. Overlap of the structures of the $\mathrm{Hg}$ - and $\mathrm{Cd}$-doped clusters with that of $\mathrm{Au}_{25}(\mathrm{SC} 2 \mathrm{Ph})_{18}{ }^{0}{ }^{39}$ The $\mathrm{Au} / \mathrm{M}-\mathrm{S}$ core units are shown on the left-hand side (ligands removed), whereas the full clusters are shown on the right-hand side (metal core units are faded, for clarity) to evidence full overlapping of the ligands (mixed colors). The color codes are: red $=\mathrm{Hg}$-doped cluster (from $\left.\mathrm{Hg}\left(\mathrm{NO}_{3}\right)_{2}\right)$, blue $=\mathrm{Hg}$-doped cluster $\left(\right.$ from $\left.\mathrm{Hg}(\mathrm{SC} 2 \mathrm{Ph})_{2}\right)$, green = $\mathrm{Cd}$-doped cluster, and yellow $=\mathrm{Au}_{25}(\mathrm{SC} 2 \mathrm{Ph})_{18}$.

\section{CONCLUSIONS}

This study was meant to obtain insights into the monodoping of $\mathrm{Au}_{25}(\mathrm{SR})_{18}{ }^{-}$clusters with foreign metal atoms. Accurate selection of chemicals, NMR analysis, electrochemical data, and critical analysis of crystallographic data allowed us to highlight hindsights into the challenge of understanding where the foreign-metal atoms are eventually located in the cluster structure, and how to characterize these quite elusive nanosystems. Using the NMR results obtained for $\mathrm{Au}_{24} \mathrm{Pt}(\mathrm{SC} 4)_{18}{ }^{0}$ and $\mathrm{Au}_{24} \mathrm{Pd}(\mathrm{SC} 4)_{18}{ }^{0}$ as a reference for the behavior expected when the cluster is doped in its central position, we show that $\mathrm{Cd}$ - and $\mathrm{Hg}$-doping does not occur at the central position. ${ }^{20} \mathrm{We}$ also show that the $\mathrm{Cd}$-doping mode is not different from that of Hg-doping, as opposed to what previously concluded..$^{21,23}$ Rather, we find that both $\mathrm{Cd}$ - and Hg-doping occurs in one of the icosahedral positions, independently of the specific ligand. Equally important, we demonstrate that the metal-exchange doping methods so-far developed always yield the very same species. Besides being important from a fundamental viewpoint, these results are also liable to impact applications of doped clusters, e.g., in catalysis, which is a promising growing area of research for atomically precise metal clusters. ${ }^{56}$ This is because proper understanding of the doping site affects the analysis of the catalytic mechanism. ${ }^{51}$ Finally, we provide a warning about reaching conclusions on the doping site on the basis of different fragmentation patterns in mass spectra, and especially, single-crystal X-ray crystallography results. We also hope that these new insights will be useful for theoreticians as a sound experimental basis to refine their calculation models.

\section{EXPERIMENTAL SECTION}

The $\mathrm{Au}_{25}(\mathrm{SC} 4)_{18}{ }^{-}$and $\mathrm{Au}_{25}(\mathrm{SC} 2 \mathrm{Ph})_{18}{ }^{-}$clusters were prepared and purified as already described. ${ }^{37,42}$ Full details on chemicals and the preparation of $\mathrm{Au}_{24} \mathrm{Pt}(\mathrm{SC} 4)_{18}{ }^{0}$, $\mathrm{Au}_{24} \mathrm{Pd}(\mathrm{SC} 4)_{18}{ }^{0}, \quad \mathrm{Au}_{24} \mathrm{Hg}(\mathrm{SC} 4)_{18}{ }^{0}, \quad \mathrm{Au}_{24} \mathrm{Cd}(\mathrm{SC} 4)_{18}{ }^{0}$, $\mathrm{Au}_{24} \mathrm{Hg}(\mathrm{SC} 2 \mathrm{Ph})_{18}{ }^{0}$, and $\mathrm{Au}_{24} \mathrm{Cd}(\mathrm{SC} 2 \mathrm{Ph})_{18}{ }^{0}$ are described in the Supporting Information.

The UV-vis absorption spectra of the clusters were obtained in DCM with a Thermo Scientific Evolution 60S spectrophotometer. The spectra were recorded with a spectral 
resolution of $0.5 \mathrm{~nm}$. The samples were at $0.2 \mathrm{mM}$ concentration in $1 \mathrm{~mm}$ cuvettes. MALDI-TOF mass spectrometry experiments were carried out with an Applied Biosystems 4800 MALDI-TOF/TOF spectrometer equipped with a Nd:YAG laser operating at $355 \mathrm{~nm}$. The laser-firing rate was $200 \mathrm{~Hz}$ and the accelerating voltage was $25 \mathrm{kV}$. trans-2-[3-(4-tert-butylphenyl)-2-methyl-2-propenylidene] malononitrile (DCTB) was used as the matrix. Depending on the experiment, the instrument was calibrated with $\mathrm{Au}_{25}(\mathrm{SC} 4)_{25}{ }^{0}$ or $\mathrm{Au}_{25}(\mathrm{SC} 2 \mathrm{Ph})_{25}{ }^{0}$. The clusters were dissolved in DCM containing DCTB to obtain $0.1 \mathrm{mM}$ solutions with a 1:400 nanocluster/matrix ratio. A $5 \mu$ solution was drop cast onto the sample plate and air-dried. All spectra were recorded using the reflector positive-ion mode.

The electrochemical experiments were carried out under an Ar atmosphere, in a glass cell at room temperature, unless otherwise stated. The solvent-electrolyte system was DCM containing $0.1 \mathrm{M}$ TBAH. The working electrode was a glassy carbon microdisk $\left(9.1 \times 10^{-4} \mathrm{~cm}^{2}\right)$, prepared and activated as already described. ${ }^{57}$ As a quasi-reference electrode, we used a silver wire, which was kept in a tube filled with the same electrolyte solution and separated from the main compartment by a Vycor frit. Its calibration was performed by addition of ferrocene at the end of the experiments; in DCM/0.1 M TBAH, the ferricenium/ferrocene redox couple has $E^{\circ}=0.460$ $\mathrm{V}$ against the $\mathrm{KCl}$ saturated calomel electrode (SCE). All potential values are reported against SCE. The counterelectrode was a Pt wire. We used a CHI 660c electrochemical workstation. In $\mathrm{CV}$, we used the positive feedback correction to minimize the ohmic drop between the working and the reference electrodes. For DPV, we used peak amplitude of 50 $\mathrm{mV}$, pulse width of $0.05 \mathrm{~s}, 2 \mathrm{mV}$ increments per cycle, and pulse period of $0.1 \mathrm{~s}$.

${ }^{1} \mathrm{H}$ and ${ }^{13} \mathrm{C}$ NMR spectra were obtained on a Bruker Avance DMX-600 MHz spectrometer operating at 599.90 and 150.61 $\mathrm{MHz}$, respectively, and equipped with a $5 \mathrm{~mm}$ TX-1 inverse probe powered by field gradients along the $\mathrm{x}, \mathrm{y}, \mathrm{z}-\mathrm{axes}$. The probe temperature was controlled $\left( \pm 0.1^{\circ} \mathrm{C}\right)$ with a Bruker BVT3000 temperature controller. The chemical shift $(\delta)$ values are given as ppm downfield from internal tetramethylsilane, for both ${ }^{1} \mathrm{H}$ and ${ }^{13} \mathrm{C}$ nuclei. To ensure a complete relaxation for all the resonances, the integrals of the proton spectra were obtained using a pre-scan delay of $10 \mathrm{~s}$. All measurements were carried out in benzene- $d_{6}$. The proton assignments were performed by COSY or TOCSY, whereas the ${ }^{13} \mathrm{C}$ chemical shift values were obtained from HMQC experiments. $\left({ }^{1} \mathrm{H}-{ }^{1} \mathrm{H}\right)$ homodecoupling experiments were performed with the standard zghd pulse sequence provided in the Bruker library.

Single-crystal X-ray data for the metal doped $\mathrm{Au}_{24} \mathrm{M}(\mathrm{SR})_{18}{ }^{0}$ clusters were collected either with a Rigaku Oxford Diffraction SuperNova dual-source X-ray diffractometer using hi-flux Mo and $\mathrm{Cu}$ micro-focus sources (Mo $\mathrm{K}_{\alpha} ; \lambda=0.71073$ $\AA$ and $\mathrm{Cu} \mathrm{K} \mathrm{K}_{\alpha} ; \lambda=1.54184 \AA$ ) and an Atlas CCD detector (University of Jyväskylä), and/or with an Oxford Diffraction Xcalibur Gemini diffractometer with Mo-radiation and Eos CCD detector (University of Padova). Data collection, reduction processes, and analytical numeric absorption corrections by multifaceted crystal models and/or empirical absorption correction using spherical harmonics, were all carried out using the program CrysAlisPro (v. 39.46). ${ }^{58}$ Structures were solved by direct methods with program
SHELXT $^{59}$ and refined by full-matrix least-squares on $F^{2}$ by SHELXL $^{60}$ in the OLEX $^{2}$ (v. 1.2.10) program. $^{61}$

\section{ASSOCIATED CONTENT}

Supporting Information. Chemicals, syntheses, NMR tables, further figures (UV-vis absorption spectroscopy spectra, NMR spectroscopy spectra, MALDI-TOF mass spectra, DPV experiments), and X-ray crystallographic analysis of the single-crystal structures of $\mathrm{Au}_{24} \mathrm{M}(\mathrm{SR})_{18}{ }^{0}$ samples. The CCDC entries 1938192-1938198 contain the supplementary crystallographic data for this paper. CIFs can be obtained free of charge via www.ccdc.cam.ac.uk/data_request/cif, or by emailing data_request@ccdc.cam.ac.uk. The Supporting Information is available on the ACS Publication website at http://pubs.acs.org.

\section{AUTHOR INFORMATION}

\section{Corresponding Author}

*flavio.maran@unipd.it

\section{ORCID}

Sabrina Antonello: 0000-0002-0090-9922

Tiziano Dainese: 0000-0002-5771-7307

Alessandro Dolmella: 0000-0003-1287-6635

Wenwen Fei: 0000-0003-0965-496X

Manu Lahtinen: 0000-0001-5561-3259

Flavio Maran: 0000-0002-8627-6491

Kari Rissanen: 0000-0002-7282-8419

Alfonso Venzo: 0000-0002-3211-0242

\section{Notes}

The authors declare no competing financial interest.

\section{ACKNOWLEDGMENTS}

This work was financially supported by the University of Padova (grant P-DiSC-2017: Gold Nose), Fondazione CARIPARO (grant: GoldCat), and the University of Jyväskylä.

\section{REFERENCES}

1. Antonello, S.; Maran, F. Molecular Electrochemistry of Monolayer-Protected Clusters. Curr. Opin. Electrochem. 2017, 2, $18-25$.

2. Jin, R. Atomically Precise Metal Nanoclusters: Stable Sizes and Optical Properties. Nanoscale 2015, 7, 1549-1565.

3. Agrachev, M.; Ruzzi, M.; Venzo, A.; Maran, F. Nuclear and Electron Magnetic Resonance Spectroscopies of Atomically Precise Gold Nanoclusters. Acc. Chem. Res. 2019, 52, 44-52.

4. Protected Metal Clusters: From Fundamentals to Applications, In Frontiers of Nanoscience; Tsukuda, T., Häkkinen, H., Eds.; Elsevier: Amsterdam, 2015; Vol. 9.

5. Jin, R.; Zeng, C.; Zhou, M.; Chen, Y. Atomically Precise Colloidal Metal Nanoclusters and Nanoparticles: Fundamentals and Opportunities. Chem. Rev. 2016, 116, 10346-10413.

6. Jin, R.; Nobusada, K. Doping and alloying in atomically precise gold nanoparticles. Nano Res. 2014, 7, 285-300.

7. Gan, Z.; Xia, N.; Wu, Z. Discovery, Mechanism, and Application of Antigalvanic Reaction. Acc. Chem. Res. 2018, 51, 2774-2783.

8. Wang, S.; Li, Q.; Kang, X.; Zhu, M. Customizing the Structure, Composition, and Properties of Alloy Nanoclusters by Metal Exchange. Acc. Chem. Res. 2018, 51, 2784-2792. 
9. Hossain, S.; Niihori, Y.; Nair, L. V.; Kumar, B.; Kurashige, W.; Negishi, Y. Alloy Clusters- Precise Synthesis and Mixing Effects. Acc. Chem. Res. 2018, 51, 3114-3124.

10. Parker, J. F.; Fields-Zinna, C. A.; Murray, R. W. The Story of a Monodisperse Gold Nanoparticle: $\mathrm{Au}_{25} \mathrm{~L}_{18}$. Acc. Chem. Res. 2010, 43, $1289-1296$.

11. Kang, X.; Chong, H.; Zhu, M. $\mathrm{Au}_{25}(\mathrm{SR})_{18}$ : The Captain of the Great Nanocluster Ship. Nanoscale 2018, 10, 10758-10834.

12. Qian, H.; Jiang, D.-e.; Li, G.; Gayathri, C.; Das, A.; Gil, R. R.; Jin, R. Monoplatinum Doping of Gold Nanoclusters and Catalytic Application. J. Am. Chem. Soc. 2012, 134, 16159-16162.

13. Christensen, S. L.; MacDonald, M. A.; Chatt, A.; Zhang, P.; Qian, H. F.; Jin, R. C. Dopant Location, Local Structure, and Electronic Properties of $\mathrm{Au}_{24} \mathrm{Pt}(\mathrm{SR})_{18}$ Nanoclusters. J. Phys. Chem. C 2012, 116, 26932-26937.

14. Kwak, K.; Tang, Q.; Kim, M.; Jiang, D.-e.; Lee, D. Interconversion between Superatomic 6-Electron and 8-Electron Configurations of $\mathrm{M} @ \mathrm{Au}_{24}(\mathrm{SR})_{18}$ Clusters $(\mathrm{M}=\mathrm{Pd}, \mathrm{Pt}) . J . A m$. Chem. Soc. 2015, 137, 10833-10840.

15. Thanthirige, V. F.; Kim, M.; Choi, W.; Kwak, K.; Lee, D.; Ramakrishna, G. Temperature-Dependent Absorption and Ultrafast Exciton Relaxation Dynamics in $\mathrm{MAu}_{24}(\mathrm{SR})_{18}$ Clusters $(\mathrm{M}=\mathrm{Pt}, \mathrm{Hg})$ : Role of the Central Metal Atom. J. Phys. Chem. C 2016, 120, 23180-23188.

16. Tian, S. B.; Liao, L. W.; Yuan, J. Y.; Yao, C. H.; Chen, J. S.; Yang, J. L.; Wu, Z. K. Structures and Magnetism of Mono-Palladium and Mono-Platinum Doped $\mathrm{Au}_{25}(\mathrm{PET})_{18}$ Nanoclusters. Chem. Commun. 2016, 52, 9873-9876.

17. Negishi, Y.; Kurashige, W.; Niihori, Y.; Iwasa, T.; Nobusada, K. Isolation, Structure, and Stability of a Dodecanethiolate-Protected $\mathrm{Pd}_{1} \mathrm{Au}_{24}$ Cluster. Phys. Chem. Chem. Phys. 2010, 12, 6219-6225.

18. Negishi, Y.; Kurashige, W.; Kobayashi, Y.; Yamazoe, S.; Kojima, N.; Seto, M.; Tsukuda, T. Formation of a $\mathrm{Pd} @ \mathrm{Au}_{12}$ Superatomic Core in $\mathrm{Au}_{24} \mathrm{Pd}_{1}\left(\mathrm{SC}_{12} \mathrm{H}_{25}\right)_{18}$ Probed by Au197 Mossbauer and Pd K-Edge EXAFS Spectroscopy. J. Phys. Chem. Lett. 2013, 4, 3579-3583.

19. Tofanelli, M. A.; Ni, T. W.; Phillips, B. D.; Ackerson, C. J. Crystal Structure of the $\mathrm{PdAu}_{24}(\mathrm{SR})_{18}{ }^{0}$ Superatom. Inorg. Chem. 2016, 55, 999-1001.

20. Wang, S.; Song, Y.; Jin, S.; Liu, X.; Zhang, J.; Pei, Y.; Meng, X.; Chen, M.; Li, P.; Zhu, M. Metal Exchange Method Using $\mathrm{Au}_{25}$ Nanoclusters as Templates for Alloy Nanoclusters with Atomic Precision. J. Am. Chem. Soc. 2015, 137, 4018-4021.

21. Yao, C.; Lin, Y.-j.; Yuan, J.; Liao, L.; Zhu, M.; Weng, L.-h.; Yang, J.; Wu, Z. Mono-Cadmium vs Mono-Mercury Doping of Au25 Nanoclusters. J. Am. Chem. Soc. 2015, 137, 15350-15353.

22. Zhou, M.; Yao, C.; Sfeir, M. Y.; Higaki, T.; Wu, Z.; Jin, R. Excited-State Behaviors of $\mathrm{M}_{1} \mathrm{Au}_{24}(\mathrm{SR})_{18}$ Nanoclusters: The Number of Valence Electrons Matters. J. Phys. Chem. Lett. 2018, 122, 1343513442 .

23. Liao, L.; Zhou, S.; Dai, Y.; Liu, L.; Yao, C.; Fu, C.; Yang, J.; $\mathrm{Wu}, \mathrm{Z}$. Mono-Mercury Doping of $\mathrm{Au}_{25}$ and the HOMO/LUMO Energies Evaluation Employing Differential Pulse Voltammetry. $J$. Am. Chem. Soc. 2015, 137, 9511-9514.

24. Yan, N.; Liao, L.; Yuan, J.; Lin, Y.-j; Weng, L.-h.; Yang, J.; Wu, Z. Bimetal Doping in Nanoclusters: Synergistic or Counteractive? Chem. Mater. 2016, 28, 8240-8247.

25. Yang, S.; Wang, S.; Jin, S.; Chen, S.; Sheng, H.; Zhu, M. A metal exchange method for thiolate-protected tri-metal $\mathrm{M}_{1} \mathrm{Ag}_{\mathrm{x}} \mathrm{Au}_{24-\mathrm{x}}(\mathrm{SR})_{18}{ }^{0}$ $(\mathrm{M}=\mathrm{Cd} / \mathrm{Hg})$ nanoclusters Nanoscale 2015, 7, 10005-10007.

26. Niihori, Y.; Hossain, S.; Sharma, S.; Kumar, B.; Kurashige, W. Negishi, Y. Understanding and Practical Use of Ligand and Metal Exchange Reactions in Thiolate-Protected Metal Clusters to Synthesize Controlled Metal Clusters Exchange reactions in thiolateprotected metal clusters. Chem. Rec. 2017, 17, 473-484.

27. Zheng, Y.; Jiang, H.; Wang, X. Multiple Strategies for Controlled Synthesis of Atomically Precise Alloy Nanoclusters. Acta Phys. Chim. Sin. 2018, 34, 740-754.
28. Yao, Q.; Yuan, X.; Chen, T.; Leong, D. T.; Xie, J. Engineering Functional Metal Materials at the Atomic Level. Adv. Mater. 2018, 1802751.

29. Heaven, M.W.; Dass, A.; White, P.S.; Holt, K.M.; Murray R. W. Crystal Structure of the Gold Nanoparticle $\left[\mathrm{N}\left(\mathrm{C}_{8} \mathrm{H}_{17}\right)_{4}\right]\left[\mathrm{Au}_{25}\left(\mathrm{SCH}_{2} \mathrm{CH}_{2} \mathrm{Ph}\right)_{18}\right]$. J. Am. Chem. Soc. 2008, 130, 3754-3755.

30. Zhu, M.; Aikens, C. M.; Hollander, F. J.; Schatz, G. C.; Jin, R. Correlating the Crystal Structure of a Thiol-Protected $\mathrm{Au}_{25}$ Cluster and Optical Properties. J. Am. Chem. Soc. 2008, 130, 5883-5885.

31. Zhu, M.; Aikens, C. M.; Hendrich, M. P.; Gupta, R.; Qian, H.; Schatz, G. C.; Jin, R. Reversible Switching of Magnetism in ThiolateProtected $\mathrm{Au}_{25}$ Superatoms. J. Am. Chem. Soc. 2009, 131, 2490-2492.

32. Jiang, D.-e.; Dai, S. From Superatomic $\mathrm{Au}_{25}(\mathrm{SR})_{18}{ }^{-}$to Superatomic $\mathrm{M} @ \mathrm{Au}_{24}(\mathrm{SR})_{18}{ }^{\mathrm{q}}$ Core-Shell Clusters. Inorg. Chem. 2009, 48, 2720-2722.

33. Walter, M.; Moseler, M. Ligand-Protected Gold Alloy ClustersDoping the Superatom. J. Phys. Chem. C 2009, 113, 15834-15837.

34. Taylor, M. G.; Mpourmpakis, G. Rethinking Heterometal Doping in Ligand-Protected Metal Nanoclusters. J. Phys. Chem. Lett. 2018, 9, 6773-6778.

35. Taylor, M. G.; Mpourmpakis, G. Thermodynamic Stability of Ligand-Protected Metal Nanoclusters. Nat. Commun. 2017, 8, 15988. 36. Alkan, F.; Pandeya, P.; Aikens, C. M. Understanding the Effect of Doping on Energetics and Electronic Structure for $\mathrm{Au}_{25}, \mathrm{Ag}_{25}$ and $\mathrm{Au}_{38}$ Clusters. J. Phys. Chem. C 2019, 14, 9516-9527.

37. De Nardi, M.; Antonello, S.; Jiang, D.; Pan, F.; Rissanen, K.; Ruzzi, M.; Venzo, A.; Zoleo, A.; Maran, F. Gold Nanowired: A Linear $\left(\mathrm{Au}_{25}\right)_{\mathrm{n}}$ Polymer from $\mathrm{Au}_{25}$ Molecular Clusters. ACS Nano 2014, 8, 8505-8512.

38. Agrachev, M., Antonello, S., Dainese, T., Gascón, J. A., Pan, F., Rissanen, K., Ruzzi, M., Venzo, A., Zoleo, A.; Maran F. A Magnetic Look into the Protecting Layer of $\mathrm{Au}_{25}$ Clusters. Chem. Sci. 2016, 7, 6910-6918.

39. Antonello, S.; Dainese, T.; Pan, F.; Rissanen, K.; Maran, F. Electrocrystallization of Monolayer Protected Gold Clusters: Opening the Door to Quality, Quantity and New Structures. J. Am. Chem. Soc. 2017, 139, 4168-4174.

40. Qian, H.; Zhu, M.; Gayathri, C.; Gil, R. R.; Jin, R. Chirality in Gold Nanoclusters Probed by NMR Spectroscopy. ACS Nano 2011, 11, 8935-8942.

41. Dainese, T.; Antonello, S.; Bogialli, S.; Fei, W.; Venzo, A.; Maran, F. Gold Fusion: From $\mathrm{Au}_{25}(\mathrm{SR})_{18}$ to $\mathrm{Au}_{38}(\mathrm{SR})_{24}$, the Most Unexpected Transformation of a Very Stable Nanocluster. ACS Nano 2018, 12, 7057-7066.

42. Dainese, T.; Agrachev, M.; Antonello, S.; Badocco, D.; Black,, D. M.; Fortunelli, A.; Gascón, J. A.; Stener, M.; Venzo, A.; Whetten, R. L.; Maran, F. Atomically Precise $\mathrm{Au}_{144}(\mathrm{SR})_{60}$ Nanoclusters $(\mathrm{R}=$ Et, Pr) are Capped by 12 Distinct Ligand Types of 5-fold Equivalence and Display Gigantic Diastereotopic Effects. Chem. Sci. 2018, 9, 8796-8805.

43. Karplus, M. Contact Electron-Spin Coupling of Nuclear Magnetic Moments. J. Chem. Phys. 1959, 30, 11-15.

44. Zerbe, O.; Pountney, D. L.; von Philipsborn, W.; Vašák, M. ${ }^{113} \mathrm{Cd},{ }^{1} \mathrm{H}$-Cysteine Coupling in Cd-Substituted Metalloproteins Follows a Karplus-Type Dependence. J. Am. Chem. Soc. 1994, 116, 377-378.

45. Zerbe, O.; Pountney, D. L.; von Philipsborn, W.; Vašák, M. ${ }^{113} \mathrm{Cd},{ }^{1} \mathrm{H}$-Cysteine Coupling in Cd-Substituted Metalloproteins Follows a Karplus-Type Dependence. [Erratum to document cited in CA120:49322] J. Am. Chem. Soc. 1994, 116, 7957-7957.

46. Henehan, C. J.; Pountney, D. L.; Zerbe, O.; Vašák, M. Identification of Cysteine Ligands in Metalloproteins using Optical and NMR Spectroscopy: Cadmium-substituted Rubredoxin as a Model $\left[\mathrm{Cd}(\mathrm{CysS})_{4} \mathrm{I}^{2-}\right.$ Center. Protein Sci. 1993, 2, 1756-1764.

47. Pountney, D. L.; Zerbe, O.; von Philipsborn, W.; Egan, J. B.; Vašák, M. ${ }^{3} \mathrm{~J}\left({ }^{113} \mathrm{Cd},{ }^{1} \mathrm{H}\right)$ Couplings in $\mathrm{Cd}(\mathrm{S}-\mathrm{Cys})$ and $\mathrm{Cd}-\mu_{2}-(\mathrm{S}-\mathrm{Cys})-$ $\mathrm{Cd}$ Moieties Follow a Karplus-like Dependence with the $\mathrm{H}^{\beta}-\mathrm{C}^{\beta}-\mathrm{S}^{\gamma}-\mathrm{Cd}$ 
Torsion Angle: Application to Protein Structure. Bull. Magn. Reson. 1995, 17, 145-147.

48. Donkers, R. L.; Lee. D.; Murray, R. W. Synthesis and Isolation of the Molecule-like Cluster $\mathrm{Au}_{38}\left(\mathrm{PhCH}_{2} \mathrm{CH}_{2} \mathrm{~S}\right)_{24}$. Langmuir 2004, 20 , 1945-1952.

49. Antonello, S.; Dainese, T.; De Nardi, M.; Perotti, L.; Maran, F. Insights into the Interface between the Electrolytic Solution and the Gold Core in Molecular Au25 Clusters. ChemElectroChem. 2016, 3, 1237-1244.

50. Antonello, S.; Holm, A. H.; Instuli, E.; Maran, F. Molecular Electron-Transfer Properties of $\mathrm{Au}_{38}$ Clusters. J. Am. Chem. Soc. 2007, 129, 9836-9837.

51. Deng, H.; Wang, S.; Jin, S.; Yang, S.; Xu, Y.; Liu, L.; Xiang, J.; $\mathrm{Hu}$, D.; Zhu. M. Active metal (cadmium) doping enhanced the stability of inert metal (gold) nanocluster under $\mathrm{O}_{2}$ atmosphere and the catalysis activity of benzyl alcohol oxidation. Gold Bull. 2015, 48, 161-167.

52. Antonello, S.; Dainese, T.; Maran, F. Exploring Collective Substituent Effects: Dependence of the Lifetime of Charged States of $\mathrm{Au}_{25}\left(\mathrm{SC}_{\mathrm{n}} \mathrm{H}_{2 \mathrm{n}+1}\right)_{18}$ Nanoclusters on the Length of the Thiolate Ligands. Electroanalysis 2016, 28, 2771-2776.

53. Antonello, S.; Perera, N. V.; Ruzzi, M.; Gascón, J. A.; Maran, F. Interplay of Charge State, Lability, and Magnetism in the Moleculelike $\mathrm{Au}_{25}(\mathrm{SR})_{18}$ Cluster. J. Am. Chem. Soc. 2013, 135, 15585-15594 54. Lee, D.; Donkers, R. L.; Wang, G.; Harper, A. S.; Murray, R. W. Electrochemistry and Optical Absorbance and Luminescence of
Molecule-like $\mathrm{Au}_{38}$ Nanoparticles. J. Am. Chem. Soc. 2004, 126 , 6193-6199.

55. Dainese, T.; Antonello, S.; Gascón, J. A.; Pan, F.; Perera, N. V.; Ruzzi, M.; Venzo, A.; Zoleo, A.; Rissanen, K.; Maran, F. $\mathrm{Au}_{25}(\mathrm{SEt})_{18}$, a Nearly Naked Thiolate-Protected $\mathrm{Au}_{25}$ Cluster: Structural Analysis by Single Crystal X-ray Crystallography and Electron Nuclear Double Resonance. ACS Nano 2014, 8, 3904-3912. 56. Du. Y.; Sheng. H.; Astruc. D.; Zhu. M. Atomically Precise Noble Metal Nanoclusters as Efficient Catalysts: A Bridge between Structure and Properties, Chem. Rev. 2019. DOI: 10.1021/acs.chemrev.8b00726.

57. Meneses, A. B.; Antonello, S.; Arévalo, M.-C; Maran, F. DoubleLayer Correction for Electron-Transfer Kinetics at Glassy Carbon and Mercury Electrodes in $N, N$-Dimethylformamide. Electroanal. 2006, $18,363-370$.

58. Rigaku Oxford Diffraction, Version 1.171.39.46, 2018.

59. Sheldrick, G. M. SHELXT - Integrated space-group and crystal-structure determination. Acta Cryst. 2015, A71, 3-8.

60. Sheldrick, G. M. Crystal structure refinement with SHELXL. Acta Cryst. 2015, C71, 3-8.

61. Dolomanov, O. V.; Bourhis, L. J.; Gildea, R. J.; Howard, J. A. K.; Puschmann, H. OLEX2: a complete structure solution, refinement and analysis program. J. Appl. Cryst. 2009, 42, 339-341.

\section{For Table of Contents Only}

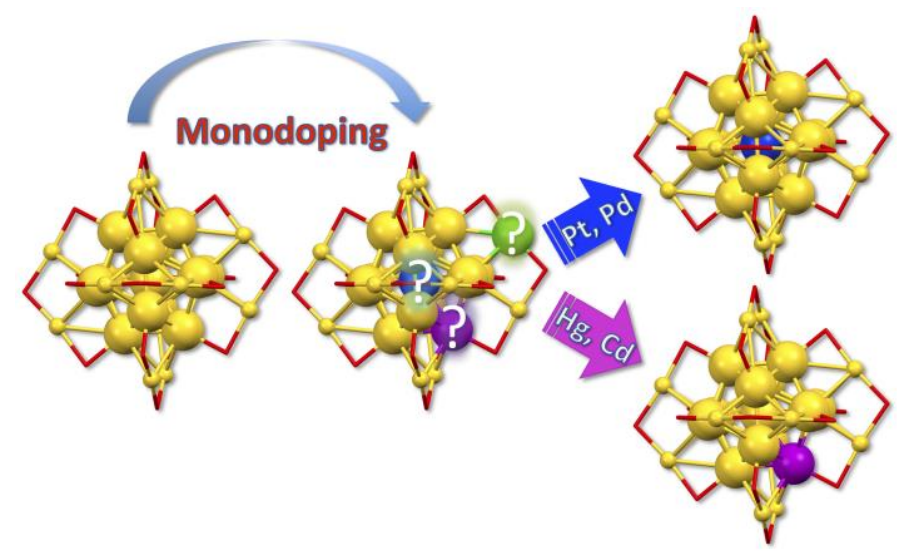

